University of Rhode Island

DigitalCommons@URI

Open Access Master's Theses

1987

\title{
Open Space and Recreation Planning in Massachusetts Communities
}

Shaun P. Burke

University of Rhode Island

Follow this and additional works at: https://digitalcommons.uri.edu/theses

\section{Recommended Citation}

Burke, Shaun P., "Open Space and Recreation Planning in Massachusetts Communities" (1987). Open Access Master's Theses. Paper 686.

https://digitalcommons.uri.edu/theses/686

This Thesis is brought to you for free and open access by DigitalCommons@URI. It has been accepted for inclusion in Open Access Master's Theses by an authorized administrator of DigitalCommons@URI. For more information, please contact digitalcommons-group@uri.edu. 
MASTER'S RESEARCH PROJECT

OPEN SPACE AND RECREATION PLANNING IN MAS8ACHUSETTS COMMUNITIES

BY

SHAUN P. BURKE

A RESEARCH PROJECT SUBMITTED

IN PARTIAL fULfILLment OF THE REQUiRements fOR THE

DEGREE AND MASTER OF COMMUNITY PLANNING

UN IVERSITY OF RHODE I SLAND

DECEMBER， 1987 
MASTER OF COMMUNITY PLANNING

RESEARCH PROJECT

OF

SHAUN P. BURKE

Approved :

Major Professor

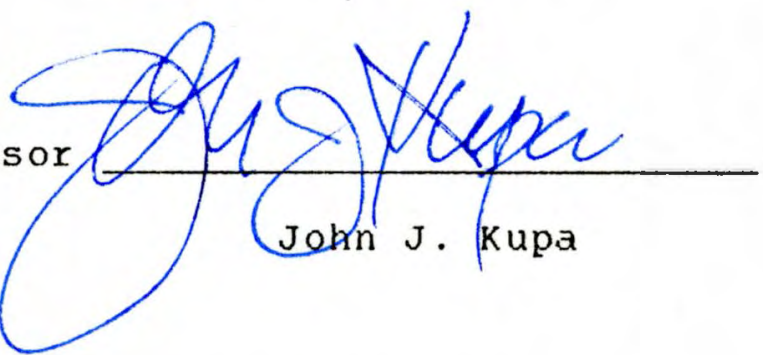

Acknowledged :

Director

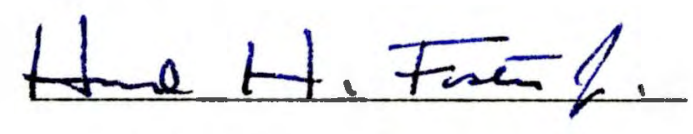

Howard H. Foster, Jr. 


\section{DEDICATION}

This thesis project is dedicated to Ellen; whose support and encouragement made it possible. 
CHAPTER ONE

The Case For Open space

And Recreation Planning ...................

CHAPTER TWO

The Open Space And Recreation Plan ............. 17

CHAPTER THREE

The Planning Process .................... 32

CHAPTER FOUR

Findings and Conclusion $\ldots \ldots \ldots \ldots \ldots \ldots \ldots \ldots \ldots \ldots \ldots \ldots$ 
TABLE OF CONTENTE - CONTINUED

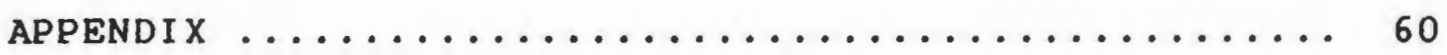

DEFINITIONS $\ldots \ldots \ldots \ldots \ldots \ldots \ldots \ldots \ldots \ldots \ldots \ldots \ldots \ldots \ldots \ldots \ldots \ldots \ldots$

BIBLIOGRAPHY $\ldots \ldots \ldots \ldots \ldots \ldots \ldots \ldots \ldots \ldots \ldots \ldots \ldots \ldots \ldots \ldots \ldots \ldots \ldots$

SUPPORT DOCUMENT

The Town of Hudson Open space And

Recreation Master Plan August, $1987 \ldots \ldots \ldots \ldots . \ldots 74$ 


\section{INTRODUCTION}

The purpose of this thesis research project is to assess the need for open space and recreation planning, review and critique the planning process, and formulate recommendations concerning the current open space and recreation planning process, at the community level, in the Commonwealth of Massachusetts.

The thesis project encompasses the various stages involved in creating an open space and Recreation Plan for a Massachusetts city or town. Issues that range from basic data gathering to identification and evaluation of accepted open space and recreational planning standards, as well as public participation in the process, are addressed. Based upon process observations, several recommendations to better facilitate community planning of open space resources and recreation facilities are suggested. In addition, an open space and Recreation Plan authored by the Master's Candidate is offered as a support document. An appendix is included that presents definitions of terms commonly used by those involved in open space and recreation planning. 
Open Space and Recreation Planning issues addressed in this project will center on three main concerns: the need for, and the difficulties associated with the collection of current and accurate socio-economic data at the community level; a review of accepted open space and recreation standards and their applicability to diverse communities; and the need for public participation and the difficulty of consensus building. In conclusion, recommendations are offered in an attempt to address the shortfalls, as perceived by the author, in the existing process. 
CHAPTER ONE

The Case For Open Space And Recreation Planning 
Planning for a community's open space and recreation needs presents the professional planner with a difflcult series interrelated of tasks. First, when initially creating a community profile, a lack of current community or neighborhood demographic data may hinder the formulation of an accurate needs assessment. U.S. Census information, by now eight years old, is often used as the primary source of community population, age and income characteristics. While this data is indispensable for generating historic trends, it may not represent the community as it exists today. Employment of other data gathering methods such as resident surveys, informal census taking or site user counts enhance the accuracy of the plan but contribute additional cost and may extend the length of the planning process. Second, application of accepted open space and recreation planning standards often proves difficult due to the vast differences between communities. The needs of densely populated urban areas, where facilities primarily focus on providing active and passive recreation areas, are very different from rapidly suburbanizing communities where need may be defined as the ability to protect groundwater resources and wildife habitats. However, most current open space and recreation standards do little to differentiate between the two. Third, public participation, by definition, is essential to successful planning activities. 
The need for a separate open space and recreation plan has often been questioned by the public. After all, since the community's Master plan contalns open space and recreation sections, must the facilities and lands inventory, goals and objectives be restated? In addition, the wisdom of allocating funds in order to inventory those facilities and city or town owned properties that many resldents already use or are aware of, especially during times of fiscal constraint, may be doubted.

One of the primary functions of the open space and Recreation plan is to create a comprehensive framework in which recreation, resource management and conservation Issues may be addressed and policles developed. The creation of a successful plan is often dependent upon the establishment of a close working relationship between varlous local commissions and city or town departments. Information vital to the planning process may be scattered among a variety of commissions and agencies. The local conservation commission may have already identified the community's natural resources, flood hazard areas and marginal lands. The community's recreation department may have an inventory of active and passive recreational facilities in addition to recreational programming and site user information. The Planning Board, town planner or 
reglonal planning agency may posses information related to local and regional lands use trends. It is the charge of the open space and Recreation plan to integrate this information, along with the goals and objectives of the participating parties, into a single document.

In rapidly growing communities open space and recreation concerns may be acknowledged, but issues of crowded public schools, an overstressed or inadequate infrastructure or intense development pressure may take precedence. Local planning efforts may be centered on subdivision review or development and application of growth management techniques. older urban centers may share similar concerns. often faced with a declining tax base, decaying infrastructure and increased service delivery costs, funding for recreation and open space planning assumes a low priority.

However, a combination of factors has often placed an increased demand upon existing sites. The rapid rate of growth in many suburban communities and a heightened awareness of the health benefits associated with passive and active recreation pursults have placed additional demand on existing facilities. An increased amount of leisure time available to the public has also placed a greater burden on community facilities. 
The awareness of the value of preserving open space in the community as a means of providing a respite from urban stress, or for the protection of wildlife habitates, ground or surface water resources has increased in recent years as the supply of vacant or undeveloped land in the community has declined. It is these three factors, increased usage of existing recreational facilities, realization of the value of open space to the community and intense development pressure on vacant lands, that have prompted many communities to reaffirm their commltment to community based recreation opportunities and preservation of valuable open space and natural resources.

The rate and degree to which urban development has replaced lands previously devoted to agriculture or open space in the Commonwealth is astounding. According to data collected by a University of Massachusetts-Amherst researcher (1), only eight percent of Massachusetts' land area was in urban use during the early nineteen fifties. Twenty years later, the urban land use figure had almost doubled. Conversely, agricultural land and open space decreased from approximately elghty-five percent of the Commonwealth's land area in 1952 to approximately seventysix percent in 1972. In the intervening years between the Macconnell Land Use study of 1971-1972 and the most recent 
complete MacConnell Land Use update conducted in 1980, land use in Massachusetts has changed further still (2). The changes are perhaps most easily identified in the eastern portion of the Commonwealth where three counties in particular have experienced tremendous development. The rate of change in these areas of exceptionally rapid growth, Barnstable County (Cape Cod), Dukes County (Martha's vineyard) and Essex County in northeastern Massachusetts are used, In Table I below, and continued on the following page, as examples of land use change.

TABLE I

\section{LAND USE CHANOE IN THRER MABSACHUBETTB COUNTIBS}

$$
1951-1980
$$

\begin{tabular}{lcccc}
\multicolumn{5}{c}{ Barnstable county } \\
Year & 1951 & 1971 & 1980 & Change
\end{tabular}

$1951-1980$

Land use (in acres)

Urban

19,090

48,692

61,471

$+2228$

Agriculture/

42,257

22,574

21,609

$-49 \%$

Open 
TABLE I

LAND USE Change In three massachusetts counties- Continued $1951-1980$

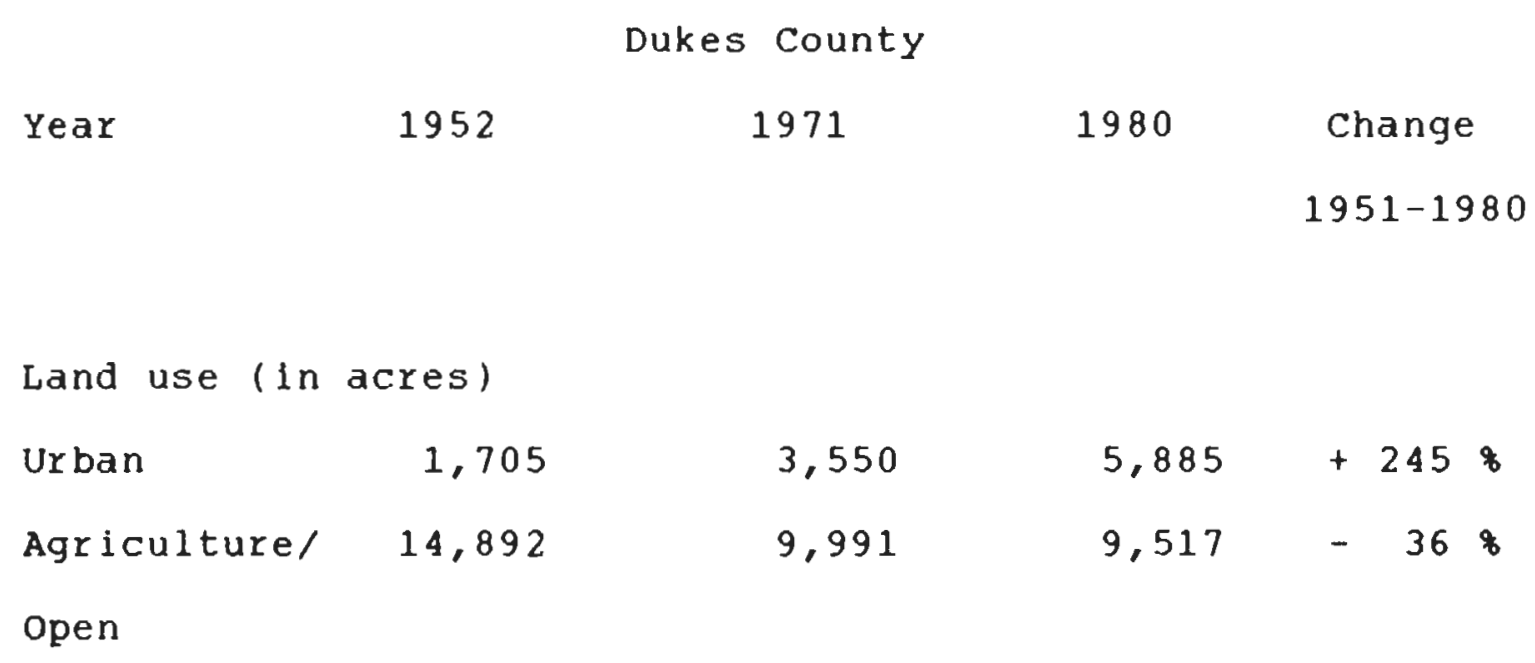

Essex County

Year

1951

1971

1980

Change

$1951-1980$

Land use (in acres)

$\begin{array}{llll}\text { Urban } & 48,067 & 81,926 & 88,676 \\ \text { Agriculture/ } & 74,364 & 41,174 & 38,376 \\ \text { Open } & & & \end{array}$

Source: MacConnell Land Use Survey, 1951/52, 1971/72, 1980 
As may be seen in Table I, land use in all three counties changed most rapidly between 1951 and 1972 . The amount of urban land in Barnstable and Duke Counties each increased by more than two hundred percent, while the amount of urban land in Essex county increased by more than eighty percent. In both Barnstable and Essex Counties the rate at which open space and agricultural lands were lost approached flfty percent.

Between 1972 and 1980 the rate of urbanization was considerably lower, as was the rate at which open space and agricultural lands were lost. There are many possible reasons why the rate of urbanization of Massachusetts counties slowed between 1972 and 1980. Rules and regulations governing subdivision of land in many communities that were inundated by development were strengthened and/or updated. New or more stringent federal and state regulations directed toward controlling or limiting development in coastal areas, flood hazard areas or environmentaliy sensitive areas were enacted. Development pressure on Massachusetts communities was also affected by the national economic downturn of the midseventies. Inflation, soaring energy costs and high interest rates contributed to a decline in the building industry that was not reversed until 1983. 
However, a strong national and statewide economic recovery in the mid $1980^{\prime}$ s once again brought development pressures to bear on many Massachusetts cities and towns. As land values escalated in the Commonwealth's urban areas, many potential home owners and businesses elected to relocate to less costly suburban communities. one result of this suburban growth was an additional decrease in the amount of agricultural land and open space. According to a publication released in 1985 by the U.S. Soll Conservation service, approximately sixty six percent of Massachusetts' land area was in agricultural or open space uses (3). A decrease of approximately ten percent in less than five years since the 1980 MacConnell Land Use Survey.

Cormunities adjacent to major surface transportation routes were especially subject to intense development pressure. Ten communities in the vicinity of Interstate Highway Route 495 and state Route 128, together with the Metropolitan Area Planning Council, organized the Minuteman Advisory Group for Interlocal Coordination (MAGIC) to address growth related issues (4). The Metropolitan Area Planning Council (MAPC) was charged with, among other tasks, developing a land use profile for each community in the MAGIC subregion (5). Preliminary investigation by MAPC of land use trends revealed that the amount of developed land in the member communities increased significantly in the 
previous flfteen years. The average increase in the amount of total developed land for the ten communities was more than 278. The range of increase in the total amount developed land in each of the MAGIC communities measured between 1971 and 1985 was equally dramatic. The Town of Boxborough at 478 recorded the highest increase, while in the Town of concord the total amount of developed land increased by $128(6)$.

The Town of Hudson, for which the Master's candidate has written the accompanying open space and Recreation Plan, experlenced an $18 \%$ increase in its total amount of developed land from 1971 to 1985. Macconnell Land Use study data indicates that land in agricultural use in the rown of Hudson was extensively affected. The total amount of agricultural land decreased approximately 258 between 1971 and 1985. In the nine year period from 1971 to 1980,54 acres, or $9 \%$ of the Town's agricultural land was lost. However, in the next five year period, 1980 to 1985, an additional 102 acres, or $18 \%$ of the remaining agricultural land was lost. As may be seen in the rable on the following page, almost every category of undeveloped land was impacted.

As the amount of undeveloped land in Hudson decreased, the amount of developed land subsequently increased, particularly commercial, industrial and residential land. 
TABLE I I

HUDSON MASSACHUSETTS LAND U8E CHANGE 1971-1985

(In Acres)

$1971 \quad 1980 \quad 1985 \quad$ Change

Land Use Category

$\begin{array}{lrrrrr}\text { Residential } & 2,097 & 2,218 & 2,334 & + & 237 \\ \text { Commercial } & 162 & 203 & 225 & +63 \\ \text { Industrial } & 132 & 233 & 245 & + & 113 \\ \text { Transportation } & 58 & 81 & 81 & + & 23 \\ \text { Urban open space } & 154 & 173 & 166 & + & 12 \\ \text { Open Areas } & 169 & 86 & 155 & - & 14 \\ \text { Agriculture } & 615 & 561 & 459 & - & 156 \\ \text { Forests } & 3,482 & 3,346 & 3,227 & - & 255 \\ \text { Wetlands } & 574 & 567 & 565 & - & 9 \\ \text { Outdoor Recreation } & 45 & 45 & 45 & & 0 \\ \text { Mining } & 136 & 111 & 121 & - & 15 \\ \text { Waste Disposal } & 56 & 56 & 57 & + & 1 \\ & & & & & 0\end{array}$

Source: MacConnell Land Use Survey 1971-72, 1980, 1985 
Clearly, the need to protect open space and agricultural lands in the face of such rapid development is of paramount importance. The aesthetic and pastoral qualities of the suburban or rural community are often endangered by such rapid land use changes.

As mentioned earlier, one of the primary functions of the open space and Recreation Plan is to create a comprehensive framework in which recreation, resource management and conservation issues may be addressed and policies developed. The open space and Recreation Plan may therefore augment and reinforce the goals, objectives and policies articulated in the community's Master plan or Growth Management Plan.

In addition to establishing a comprehensive planning framework, the open space and Recreation Plan serves two other essential functions in the community which warrant brief mention. First, the Commonwealth of Massachusetts requires that every community must update their open space and Recreation Plan every flve years. An update is requixed in order to qualify the community for participation in federal and state open space and recreation funding programs, certainly no small incentive to maintaining a current plan. Second, the plan may be viewed as an educational tool and resource. The open space and 
Recreation Plan highlights local environmental issues, recreational opportunities and identifies specific goals and priorities. The plan should assist in local decision making by allowing the community's citizens and officials, as well as developers, to compare development proposals to the goals and policies set forth in the plan. The open space and Recreation Plan should also act as an information base of the community's natural resources.

In conclusion, it may be stated that the open space and Recreation plan is far from being a static or redundant planning document. The Plan is a proactive means of preserving and/or conserving the community's natural features and resources. It is also a method by which current and future recreational needs may be identified and addressed. The plan should be flexible enough to allow for modification from time to time, in order to adjust for change in recreational demand, community demographics or fiscal capabilities. 
FOOTNOTES

(1) "Remote Sensing 20 Years of Change in Massachusetts $1951 / 52-1971 / 72 ", \quad$ p. $50-51$

(2) "Land Use Update" Research Bulletin 686, p. 4

(3) "Massachusetts soll \& Water Conservation", February 1985, p. 2

(4) The ten Massachusetts communities that comprise the MAGIC subregion are: Acton; Boxborough; Carlisle; Concord; Hudson; Littleton; Marlborough; Maynard; stow; and sudbury.

(5) Conflicting and compatible Land Uses and Intensities In The MAGIC subregion, p. 1

(6) Conflicting and Compatible Land Uses and Intensities in The MAGIC Subregion, p. 7 
CHAPTER TWO

The Open Space And Recreation Plan 
Massachusetts cities and towns have been required to establish Open space and Recreation Plans for more than twenty years. Beginning in the mid 1960s, communities wishing to enjoy the benefits of participation in state and federal conservation grant programs were charged with establishing a plan for natural resource conservation and land acquisition. According to Hermann H. Field, a Board Member of the Massachusetts Association of Conservation Commissions, "...those early plans were very sketchy and angled primarily toward securing those state and federal dollars, thereafter to be forgotten" (1). However, the Commonwealth had created guidelines by which plans could be reviewed and proposed acquisitions evaluated. "The most important requirement was that communities prepare a conservation plan to be updated every five years in order to maintain their eligibility for funding" (2).

By the mid 1970s the Commonwealth of Massachusetts had adopted stricter planning guidelines in order to enhance the quality and broaden the scope of open space preservation plans. The recreation needs of the community were now to be incorporated with the community's conservation plan into a new Open space and Recreation Plan. Additionally, "...participation in the Division's (3) grant programs be dependent on the willingness of communities to assume their 
"fair share" of housing growth ... and to comply with affirmative action regulations promulgated by the secretary of Environmental Affairs in 1978" (4). With the exceptions of several minor modifications over the Intervening years, the guidelines established in the 1970 s remain in use today.

state guldelines mandate that current open space and Recreation Plans contain seven separate sections. These sections consist of background information on the subject community, a statement of participation and methodology, a statement of goals and objectives, an inventory of existing open space and recreation sites, a needs analysis, a five year action program and written comments from the planning board, local commissions and the regional planning agency. The required sections will be briefly described in the following paragraphs.

Background information on the subject community is usually conveyed in the form of a community profile. Included in the profile are a broad range of socio-economic characteristics, a description of the community's topography and natural features and its relation to neighboring cities and towns. Population trends and density, the age distribution of residents, income levels, employment characteristics, school enroliment trends and special 
populations, e.g. handlcapped, elderly, low-lncome households, or minorities, may be included as socio-economic background information. Current land use and land use trends, historic sites, the local transportation network and water supply and sewage disposal systems should also be included. Physical characteristics such as soils, slope, flood hazard areas, surface and ground water resources or other natural resource information may be included.

The statement of participation is generally a list or short description of the agencies, boards, civic organizations or citizens actively involved in the planning process. An explanation of the methodology employed in the formation of an open space and Recreation Plan usually accompanies the statement of participation. The information contained in the methodology section may include, but is not limited to: sources of background and demographic data, site inspection methods and techniques, survey results and a discussion of open space and recreation standards selected for use in the plan.

The community's open space and recreation goals and objectives statement is of primary importance for the goals statement will form the cornerstone on which local policy will be based. The goals and objectives in an updated plan may be based on goals articulated in a prior plan. 
Goals transferred from one plan to another must be reviewed in open meetings, and amended, expanded, updated or deleted as necessary, to conform to current demographic and economic conditions and according to public consensus. Additional goals and objectives may be included, as needed, to supplement previous goals or address new issues.

An inventory of the community's conservation areas and recreation sites is also recommended for inclusion. The inventory should cover "... all public (federal, state and municipal), semi-public, and private (but used by the public) conservation and recreation sites in the community" (5). The Inventory should present a short profile of each site, ldentifing it by name, with ownershlp, acreage, zoning and the name of the agency responsible for management of the site comprising a portion of the profile. Additional information describing the site's condition, natural features or special qualities may be included in the site proflle.

A community open space and recreation needs analysis follows the inventory. Essentially, a needs analysis is a determination of need based upon current supply and demand. In other words, if demand exceeds supply, a need may be said to exist. Two general measures of need are often used in open space and recreation planning. A ratio of open space 
and recreation land area to the community's population may be generated. The ratio is then compared to accepted planning standards to determine if, based on accepted standards, the community contains a sufficient amount of open space and recreational sites for its residents. A second method often used to measure need is the identification of a service area for each site. A service area may be deflned as the geographic area from which a site will attract users. As with population to land area ratios, service areas for open space and recreation areas are based upon accepted planning standards. Following a determination of existing demand a projection of future demand should be made. The projection may be based on population and land use trends contained in the community profile.

A five year action program concludes the body of the plan. Based primarily upon a completed needs assessment, the action program may recommend specific acquisitions be undertaken or improvements to community facilities be made. Possible funding sources should be identified for each recommendation. Each recommendation is assigned a priority in light of the community goals articulated earlier in the plan, avallability of state and federal funding and ease of implementation. 
Prior to submitting the completed Open space and Recreation Plan to the Massachusetts Division of Conservation services for consideration, written comments about the plan should be solicited from several sources. Local boards and commissions, as well as the regional planning agency, should examine the Plan. Following review of the plan, the community's planning Board and Conservation commission should append written comments. These comments may include affirmation of local support for the document or acknowledgment of the relationship of the Plan to the community's overall goals or growth plan. Review by a regional planning agency should be conducted to assess the impacts or affects the Plan may have on the region. Nelghboring communities often share the same resource base, e.g. ground water, and may be facing similar issues and pressures as the subject community. An effort to share information or protect valuable finite resources may be coordinated by the regional agency. In addition, the combination of a local and regional perspective in the review process may assist in ldentifying strengths and weakness' in the open space and Recreation Plan.

In summary, the Open space and Recreation Plan consists of six distinct informational sections and a seventh section containing written comments on the plan. The plan contains a community profile, including socio-economic 
background information and natural resource data. An identification of the participants and a description of the methodology chosen follows. The Plan's goals and objectives statement is fundamental to a successful plan. An inventory and profile of the community's recreation and conservation areas comprises another section. An assessment of the community's open space and recreation needs, current and future, follows. A five year action program prioritizes future improvements and acquisitions. Finally, written comments from local boards and commissions, in addition to the regional planning agency, are appended to the open space and Recreation plan prior to its submittal to the Massachusetts Division of Conservation Services.

In order to qualify for participation in federal and state funding programs, a completed copy of the open space and Recreation Plan should be forwarded to the Massachusetts Division of Conservation services prior to the annual funding round deadine of August 31. The contents of each plan are measured against a program rating system to determine the plan's compliance to Division of Conservation Service guidelines and therefore eligibility for grant funding. 
The Division rates each plan on a scale ranging from one to one hundred points for the Self Help program. The scale is expanded by five points, to a range of from one to one hundred five points, for the Land and water Conservation Fund and Urban self Help Program.

Divided into two elements, the program rating system welghts both demographic factors and profect quality considerations. Maximum possible total rating points for the self-Help program are equally divided, 50 points each, between demographic and project elements. However, for the Land and Water Conservation Fund and Urban Self-Help Programs a maximum of 40 rating points may be given in consideration of demographic factors and a maximum of 65 rating points may awarded as profect points.

Although many other open space and recreation programs exist, these three programs have been chosen as the unit of measure because one or more of the programs may be used in all of the Commonwealth's cities and towns. Table III, found on the following pages, identifles the method used by the Massachusetts Division of Conservation Services to allocate system points for each program. 


\section{TABLE I I I \\ ALLOCATION OP PROGRAM RATING SYSTEM POINTS}

$\begin{array}{ll}\text { GRANT PROGRAMS } & \\ \text { SELF-HELP } & \text { LAND and WATER } \\ & \text { CONSERVATION FUND, } \\ & \text { URBAN SELF-HELP } \\ \text { (Points) } & \text { (Points) }\end{array}$

ELEMENT ONE

Demographic Factors

Population density

10

10

Percent of households

below poverty level

10

10

Median Eamily income

10

10

Equalized valuation

per capita

10

10

Public transportation

avallabll1ty

5

Service to population

centers

5 
TABLE III

ALLOCATION OP PROGRAM RATING SYSTEM POINTS- Continued

$\begin{array}{ll}\text { GRANT PROGRAMS } & \\ \text { SELF-HELP } & \text { LAND and WATER } \\ \text { CONSERVATION FUND, } \\ \text { URBAN SELF-HELP } \\ \text { (Points) } & \text { (Points) }\end{array}$

ELEMENT TWO

Project Quality

Plan consistency

with SCORP (6)

10

25

Water resource

protection

10

10

Unlque natural,

historical, or

cultural features

8

WIldlife resources

5

Multiple use

7

Project innovation

$-$

10 
TABLE I I

ALLOCATION OF PROGRAM RATING SYSTEM POINTS- Continued

$\begin{array}{ll}\text { GRANT PROGRAMS } & \\ \text { SELF-HELP } & \text { LAND and WATER } \\ & \text { CONSERVATION FUND, } \\ & \text { URBAN SELF-HELP } \\ \text { (Points) } & \text { (Points) }\end{array}$

ELEMENT TWO

Project Qual1ty

Intergovernmental

effort

10

Planning and

implementation

10

Public transit

3

Project scope

3

Special needs

$-$

4

TOTAL POINTS

100

105

Source: "Open space and Recreation plans: The state Agency's Role", Massachusetts Division of Conservation Services 
As may be seen in Table III, demographic factors are given essentially equal welght in both program rating systems. However, 10 additional points may be awarded in the Self-Help program for accessibility to public transportation and proximity to population centers. The awarding of project points does, however, vary a great deal. The variation may be attributed to the different focus given each of the grant programs. While the Self-Help Program is geared toward preserving the natural resource base of rural and suburban communities, the Land and water Conservation Fund and the Urban self-Help program are directed at developing recreational opportunities and conservation of water resources in more intensely developed communities $(6)$.

Generally, the details of acquisition or construction of a specific project ldentified in the plan will be elaborated upon in a separate document and an accompanying grant application. Grant announcements are made by the Director of the Division of Conservation services several months after the August filing deadilne, following review of both the Open space and Recreation Plan and the detailed project plans. 
This Chapter and the proceeding chapter have dealt with the required contents of an open space and Recreation Plan and need for open space and recreation planning in rapidly developing Massachusetts communities. The subsequent two Chapters of this thesis project wlll outline the process of open space and recreation planning and suggest means by which issues raised during the process may be addressed. 
FOOTNOTES

(1) "WHY OPEN SPACE AND RECREATION PLANS ?",p. 4

(2) "Why OPEN SPACE AND RECREATiON PLANS ?", p. 4

(3) Massachusetts Division of Conservation Services

(4) "OPEN SPACE AND RECREATION Plans: THE STATE AGENCy's ROLE", P. 5

(5) "PREPARING AN OPEN SPACE AND RECREATION MASTER PLAN", p. 2

(6) Additional information concerning the self-Help, Urban Self-Help and Land and Water Conservation Fund may be found in the appendix of the support document. 


\section{CHAPTER THREE}

The Open space And Recreation Planning Process 
Public involvement in the preparation of the community's Open Space and Recreation Plan should be strongly encouraged from the beginning. Residents should be encouraged to attend public meetings where the nature, purpose and scope of the proposed plan wlll be clearly stated. Informational bulletins may be distributed or news releases published to stimulate public interest and awareness. Local boards, commissions and recreation organizations should also be encouraged to lend their knowledge, support and expertise. All parties should work together to create a plan mindful of natural resources and responsive to community needs. According to planning consultant Alfred J. Lima, "The best open space plan--and the one most likely to be implemented--1s a plan that emerges from a maximum amount of community participation" (1).

Prior to the start of data gathering and analysis tasks, a literature search must be conducted. Past and current planning documents, both local and reglonal, should be reviewed. Special consideration should be given to the community's Master plan and the state Conservation and Outdoor Recreation Plan or SCORP Plan. The Master Plan may provide background information on the community, while its goals and objectives statement will assist in developing open space and recreation goals. The Master Plan, 
depending upon when 1 t was written, may also be a valuable source of demographic and socio-economic information.

Information contained in the SCORP Plan can provide a state-wide and regional perspective to the local open space plan. More importantly, the SCORP plan may act as a model for local planning efforts. The SCORP plan shares many of the features, e.g. a goals statement, an inventory of recreation facilities and natural resources and an action program, included in the community based plan. By following the example set by SCORP, combined with limited assistance from the Massachusetts Division of Conservation Services, local governments who may not be able to afford the services of a professional planner, may be able to write a basic Open space and Recreation Plan. However, in the Commonwealth of Massachusetts local conservation districts often make available both technical and/or financial assistance to communities wishing to update an open space or Recreation Plan.

In addition to planning reports, there are several other possible sources of open space and recreation information. The Massachusetts Department of Commerce has developed a monograph for every Massachusetts community. Written as recently as 1984, the monographs include a wealth of basic information about each community. Included 
in the monograph's ten to twelve pages, is housing and demographic data, economic base and employment information and a page of background information for the subject community. The city or town monograph is perhaps the most helpful short document that may be used to compose the community profile section of the open space plan.

Conservation and wildilfe publications should be viewed as possible sources of relevant data. These organizations often generate documents that may assist the planner in identifying the local resource base, endangered plant or wildife habitats or local land use trends. The Nature Conservancy and the Massachusetts Audubon Society are two examples of such organizations. Indeed, the Massachusetts Audubon society has recently released a comprehensive study, "Losing Ground: The Case For Land Conservation In Massachusetts" (2) that tracks the loss of open space in Massachusetts communities between 1981 and 1986 .

The literature search should extent to include a compllation of accepted open space and recreation planning standards. Examples of planning standards may be found in the SCORP Plan, prior planning reports or planning textbooks. Planning agencies and recreation organizations may also publish open space and recreation standards or guidelines ( 3 ). 
Upon completion of the literature search, data gathering and analysis activities should be initiated. The importance of data gathering to the plan is three fold. First, demographic and socio-economic data is needed to complete the community profile. Second, the number, size and ownership of open space and recreation sites in the community must be ascertained to complete the community inventory section of the plan. Third, socio-economic and demographic data must be compared to the open space and recreation inventory to develop the needs analysis section.

The primary source of accurate detalled demographic and economic information is the decennial census conducted by the U.S. Department of Commerce, Bureau of the Census. Age, income, employment and housing characteristics of the subject community may all be found in Census publications.

In addition to accuracy and detail, the various levels at which census data is aggregated encourages its use in community planning. U.S. Census data may be examined at the federal, state or county level, as well as by Metropolitan statistical Area (MSA), city or town, census tract, or by block. Generally, data will be collected from the most recent, 1980, and the two preceding, 1970 and 1960, U.S. Census decennial publications in order to identify trends. 
However, toward the middle or end of the decade the characteristics of the community may differ considerably from characteristics recorded five to nine years earlier. Thus, the value of U.S. Census data to community planning may diminish as the next census nears. For those planning in the middle or end of the decade the lack of current detailed information concerning the subject community is perhaps the most formidable obstacle to establishing an accurate open space and recreation needs assessment.

other sources of population or economic information may be used to supplement Census data. The Commonwealth of Massachusetts conducts a census of population for each city and town in the middle of each decade. It is therefore possible to use 1985 population figures rather than the community's recorded in 1980 to assist planning activities. Population information by ward or voting precinct may also be used to determine population distribution in general terms. Unfortunately, all of these supplementary sources lack the detall of U.S. Census information.

The Massachusetts Department of Employment security is a source of economic information often utilized by planners when U.S. Census is deemed no longer current. The Department of Employment security records the number of jobs 
by employment sector, average wage by sector and the total number of Jobs annually for each Massachusetts community. Here again, Information avallable from the Commonwealth lacks the detail found in the U.S. Census. Similar to population information generated by the Commonwealth, employment data is available only for the entire community, not at the census tract or block level.

The lack of current detalled demographic information may have an adverse affect on the Open space and Recreation Plan, especially in the needs analysis section. A lack of current data may result in a nelghborhood needs analysis based upon 1980 rather than 1987 population and population distribution patterns. Construction of additional housing units or institutional residences after the Census may have altered nelghborhood open space and recreation need as defined by the use of 1980 Census material. Moreover, U.S. Census data is generally the only source of age distribution information available to the community. other aspects of the community's demographics may have also experienced great change since the last Census. As a result of an aging population, in-migration, out-migration trends or changes in local birth or death rates, recreational demand may have changed slgnificantly. 
subsequent to assembling and analyzing demographic and economic data for the subject community, data collection should begin for the community-wide inventory of open space and recreation facilities. A complete list of open space areas and recreation sites may often be compiled in short order by contacting several local sources.

The community's parks commission or recreation department usually maintains an updated list of all sites under its jurisdiction. The parks commission or recreation department may have a description and equipment list avallable for each site. The local conservation commission will also be a source of information concerning the size, location and name of local conservation areas.

Local tax rolls too, may provide information on other open space and recreational land in the community. The amount of property held by various governmental entities, non-profit organizations or by private individuals receiving tax benefits associated with open space protection or farmland preservation programs, along with the property's value and location will be contained in the community's tax records.

The assembled data should be combined into one complete list and compared to prior open space and recreation 
documents for discrepancles.

Projected and pending acquisitions should be noted, but not included in the inventory.

To complete the community open space inventory each site should be inspected and note taken of intended use, equipment, if any, and condition of the site. Other factors such as lighting, buffers, fences, unlque features and adjacent land uses may also be included. The zoning classification for each site may be determined from the approprlate zoning map. A map of recreation sites and conservation areas, suitable for inclusion in the completed plan, is the final step in the data gathering and analysis process.

Following completion of the community profile and open space and recreation inventory a public meeting should be encouraged. The meeting should be advertised in such a manner as to stimulate curiosity and generate interest in the plan and 1 ts preliminary findings. The purpose of the meeting should be threefold. First, the meeting should attempt to explain the planning process, provide a review of proposed goals and reaffirm the need for the community to make a commitment to conservation of finite natural resources and a continuation or enhancement of local recreation opportunities. Second, the meeting should 
present findings assembled thus far and solicit public comment on the preliminary findings. The third function of the public meeting is to promote discussion among residents of the community of percelved open space and recreation needs.

Attendees should be asked to record their names along with the name of the agency, organization, or neighborhood group they represent. A sign-in sheet may either be posted at the entrance to the room where the meeting will take place or be passed around the room prior to the start of the meeting. The sign-in sheet serves two functions; names on the sign-in sheet may be included in the required statement of participation. In addition, the sign-in sheet may assist the planner in getting to know community residents.

Having completed what may be described as the first third of the open space and recreation planning process, the planner's next challenge is to select appropriate planning standards and to conduct a needs analysis. As mentioned in Chapter Two, a needs analysis, in its most modest form, is a supply versus demand equation. Or, a comparison of the community's existing open space and recreation opportunities to projected open space and recreation demand. 
The needs analysis employed in this thesis project is essentially the application of accepted open space and recreation standards to the community's current population and the existing open space and recreation inventory.

Several sources of accepted open space and recreation planning standards were identified during the literature search conducted in the initial planning stage. The accompanying tables provide several examples of accepted open space and recreation standards.

TABLE IV

\section{ELBCTED OPEN BPACE AND RECREATION PLANINO BTANDARDB}

Type

$\begin{array}{cccc}\text { Acres/1000 } & \text { Size } & \text { Population } & \text { Service } \\ \text { People } & \text { Range } & \text { Served } & \text { Area }\end{array}$

Playlot

na

$2500 \mathrm{sq} \cdot \mathrm{ft}$.

500-2500 subnelghborhood

to 1 acre

Vest-Pocket na $2500 \mathrm{sq} . \mathrm{ft} . \quad 500-2500$ subnelghborhood

Park

to 1 acre

Ne I ghborhood

2.5

min. 5 acres 2000 -

$.25-.50 \mathrm{miles}$

Park

to 20 acres 10000 
TABLE IV

\section{SELECTED OPEN SPACE AND RBCREATION PLANNING STANDARDS}

\section{Continued}

\begin{tabular}{|c|c|c|c|c|}
\hline Type & $\begin{array}{l}\text { Acres } / 1000 \\
\text { People }\end{array}$ & $\begin{array}{l}\text { Size } \\
\text { Range }\end{array}$ & $\begin{array}{c}\text { Population } \\
\text { served }\end{array}$ & $\begin{array}{c}\text { Service } \\
\text { Area }\end{array}$ \\
\hline $\begin{array}{l}\text { District } \\
\text { Parks }\end{array}$ & 2.5 & $20-100$ acres & $\begin{array}{l}10000- \\
50000\end{array}$ & $.50-3$ miles \\
\hline $\begin{array}{l}\text { Large Urban } \\
\text { Park }\end{array}$ & 5.0 & $100+$ acres & $\begin{array}{l}1 \text { each } \\
50000\end{array}$ & $\begin{array}{l}1 / 2 \text { hour } \\
\text { driving time }\end{array}$ \\
\hline $\begin{array}{l}\text { Regional } \\
\text { Park }\end{array}$ & 20.0 & $250+$ acres & $\begin{array}{l}\text { entire } \\
\text { small }\end{array}$ & $\begin{array}{l}1 \text { hour } \\
\text { driving time }\end{array}$ \\
\hline
\end{tabular}

Source: The National Recreation and Park Association na $=$ not applicable

sq.ft. = square feet

The National Recreation and Park Association also suggests that a standard percentage of a community's land area should be reserved for open space and recreation purposes. 
"The National Recreation and Park Association recommends that a minimum of $25 \%$ of new towns, planned unit subdivisions and large developments be devoted to park and recreation lands and open space" (4).

\section{TABL: IVa}

\section{BLECTED OPEN 8PACE AND RECREATION PLANNING 8TANDARDS}

Type

Acres $/ 1000$

Population size of site

Idea 1

MInimum

4 acres

10 acres

Ne Ighborhood 2.0

Parks

Playfields

Community

3.5

Parks

District

2.0

200 acres 100 acres

Parks

Regional

15.0

500 to

2 acres

5 acres

15 acres 10 acres

100 acres

40 acres

Parks and Reservation 1000 acres
$1.5 \mathrm{miles}$

2.0 miles

Radius of

Area Served

0.5 miles

0.5 miles

$3.0 \mathrm{miles}$

Source: Joseph De Chiara and Lee Koppleman (5) 
While many of the planning standards are similar, there are variations in vocabulary, site area requirements and the geographic limits of service areas. The lssue at this juncture is whether or not the standards chosen for use in the open space plan may be applied directly to the subject. community or if the standards require adjustment due to a unique situation or feature in the community.

In general, any or all of the standards reviewed may be successfully used to measure the approximate recreational need in most communities. However, in the case of intensely built or densely populated areas, where vacant land is nonexistent or scattered about the community in small noncontiguous parcels, direct application of most accepted planning standards would meet with little success. One example is the city of Chelsea, Massachusetts. Total land area in the community is approximately one and elght tenths square miles, with a 1980 population of approximately 25,000 persons, yet the city of chelsea owns a total of only twenty-six acres of open space and recreation land. "Indeed, direct application of national standards to Chelsea would call for three to six times the amount of recreational space the city currently owns" (6). 
In this extreme example, the standards employed profect need based upon a proscrlbed ratlo of open space or recreation land area to population. Unfortunately, the standards gave no consideration to the fact that Chelsea is almost entirely built, with no remaining undeveloped areas of significant size. To suggest that the City of Chelsea seek to acquire an additional 75 to 150 acres of land to meet recreational demand based on accepted planning standards is ludicrous. However, the standards work in that they did generate a recommended amount of open space and recreation land area, albeit with limited applicability.

As may be understood from the above example, the problem with accepted open space and recreation standards is not the failure of the standards to approximate community need, but the failure of most standards to take into account factors other than population. Prior to a determination of local open space and recreation need based solely upon accepted planning standards, the planner must consider local and regional circumstances that affect 
local need. Local fiscal constraints, the community's source of potable water and proximity to regional open space areas and recreation sites must be considered. Information concerning the availability of undeveloped land, the degree of development pressure and the community's history, physical features and character should be used to supplement accepted open space and recreation planning standards.

The needs analysis should be extended to include future open space and recreation need. Conducted in a manner similar to current need, the primary basis for estimating future need is accepted planning standards. Projection of future need must also include the considerations mentioned in the preceding paragraph. Special emphasis should be given to population projections and land use trends.

A third public meeting should be held upon completion of the needs analysis section. After recapping what has been accomplished to date, an explanation of accepted planning standards and a short description of a needs analysis should precede identification of open space and recreation needs. Charts, tables or graphs may be utilized to assist the planner in presenting both concepts and facts. The public should be encouraged to comment upon the findings of the needs analysis. Preliminary recommendations based 
upon the needs analysis may be offered at this time. Preliminary recommendations should be discussed and a prioritization of community open space and recreation needs undertaken. Attendees should be informed that the planning process is approximately two thirds complete, with only Einal recommendations and the five year action plan remaining.

Contents of the final recommendations section and the priorities established in the five year action plan are a direct result of public participation. While the Plan's findings are based on the needs analysis, community input and support are required to establish the validity of the Plan's recommendations. To create an action plan in which acquisitions, improvements and maintenance issues are assigned priorities, the planner must synthesize opinions volced at public meetings with the goals and objectives that underlie the Open Space and Recreation Plan.

The recommendations section and five year action plan conclude the portion of the plan written by the community or the planner. Final recommendations may be included for each site, or for only those sites in need of improvement. Proposed acquisitions should also be included, as should new or modified open space and recreation ordinances or policy. 
The action plan should be a timeline for implementing recommendations contained in the previous section. Maintenance programs and initiatives may be outlined, funding sources identified and acquisitions or improvements placed in a Eive year time frame. A fourth and last public meeting may be held to present the Plan's final recommendations and action plan.

The final public meeting has two basic functions. First, the completed Open space and Recreation Plan, Including final recommendations and action plan is presented. The second function of the last meeting is to inform the public of the next steps involved in the process of submitting the plan to the Massachusetts Division of Conservation services.

The completed Plan must be submitted to the subject community's Planning Board for written comment and adoption. All other agencies participating in the planning process, e.g. the conservation commission and regional planning agency, should also receive copies of, and supply written comments on, the completed plan. The final step in the creation of an Open space and Recreation Plan is to submit the open space and Recreation plan to the Massachusetts Division of Conservation Services as proof of an updated Plan meeting all criteria outlined by the state. 
FOOTNOTES

(1) "PREPARING AN OPEN SPACE AND RECREATION MASTER PLAN", p. 1

(2) "Losing Ground: The Case For Land Conservation In Massachusetts", Daniel S. Greenbaum and Arleen O'Donnell, Massachusetts Audubon Society, Educational Resources Department, South Great Road, Lincoln, Massachusetts, October, 1987

(3) National Recreation and Park Association, Recreation, Park, and Open Space Standards and Guidelines, National Recreation and Park Assoclation, Washington, D.C., 1983

(4) National Park, Recreation and Open space standards, 1971, p. 12

(5) Planning Design Criteria, p. 203

(6) "City of Chelsea - Open space and Recreation Master Plan, June $1987^{\prime \prime}$, p. 16 


\section{CHAPTER FOUR}

Findings and Conclusion 
As with most planning processes, the open space and recreation planning process presents the professional or non-professional planner with several challenging issues. of the many issues encountered, three issues in particular represented areas of mafor concern during this thesis project. Social and economic information taken from the 1980 U.S. Census for use in the plan was outdated and may be of questionable value. Accepted open space and recreation standards are based on a community's demographic characteristics, while the avallability of vacant land and existing land use in the community are given little consideration. Finally, public interest and participation in the open space and recreation planning process is urgently needed, yet was often lacking. While no single issue is capable of negating the merit of planning for a community's open space and recreation needs, all three issues may have a strong affect on the outcome of the Plan.

First, planners utilizing U.S. Census data as the primary source of socio-economic information must beware of the pitfalls of relying on what may be outdated information. The community's current population may be under-represented or over-represented by the use of seven year old data. Median age and Income may have significantly changed. An increase or decrease in the number of housing units in a 
community or a new pattern of population distribution may have occurred. Any of the above factors may adversely affect the accuracy of an open space and recreation needs assessment. The utilization of incorrect data may endanger the crediblilty of the plan and the planner. The extensive use of out-dated Census information in formulating an open Space and Recreation Plan could mislead the planner to make faulty need and demand assumptions.

other sources of demographic information are available to the planner and may be used to supplement U.S. Census data. Population data collected by the Commonwealth of Massachusetts in 1985 may be used to update federal sources; the subject community's Town or clty clerk may have yearly population data. However, the accuracy of population data collected by both the Commonwealth and local governments has frequently been questioned by elected officlals and social service agencies. Detractors often contend that the state and local census figures often under-count those portions of the population in most need of public services. It has been alleged that residents of the community that are poor, illegal aliens or both, may not be counted or may avold being counted. Although some question may exist as to the absolute accuracy state and local census information, it may be used by the planner to gauge general population trends. 
Information on the recreational needs of special populations in the community may usually be obtained from local sources. The superintendent of schools may provide information on school age population trends, special needs students and programs, and recreational opportunities offered by the community's school system. Social service agencies offer the planner a valuable source of information about the special populations they serve. Knowledge of the recreational needs of the elderly, the handicapped or the community's non-English speaking population may greatly assist the planner in formulating an accurate needs assessment.

The open space and recreation planner should attempt to coordinate his or her data gathering and research activities with other planning efforts. Data collection tasks and expenses may be shared between local and regional housing, transportation, or growth management study groups. Private sector social service agencies may wish to jointly participate with the public in research efforts to reduce the high cost of conducting client surveys and conducting outreach programs.

By allocating more time and resources to basic data collection the planner can ensure that the basic tenets and 
underlying assumptions of the plan are as accurate as possible. The involvement of other public and private service agencies in data gathering activities and data sharing therefore reduces the planner's reliance on U.S. Census data.

The second major issue that arose during the open space and recreation planning process was the use of accepted planning standards as a measure of community need. Generally accepted open space and recreation standards are population based, with little attention given to other community characteristics. The planning standards reviewed during the course of this thesis profect appear to be more idealistic than realistic. Fiscal constralnts in the community are ignored by the standards, as are the availability of undeveloped parcels of land and the community's existing land use patterns. In addition, current open space and recreation standards do not address the fundamental differences between stable urban areas and rapidly expanding communities or urban and rural settings.

cleariy, some adjustment of accepted open space and recreation standards may be needed before the standards can be applied to individual communities. A means of updating standards currently in use to reflect the realities of budget constraints and differing community characteristics 
must be found. The standards should also acknowledge the affects that special populations and age distribution in the community have on open space recreational demand. At present the planner must adapt the standards to each community based upon his or her understanding of that community. The result is that open space and recreation standards are more of a guide to emulate than a specific set of criteria to which the planner must adhere.

The need to stimulate public interest and promote public participation in the open space and recreation planning process is the third key issue. If an open space and Recreation Plan is to be successfully established and implemented, community input and support are essential. Residents must become actively involved in the planning process from start to finish. Concerned citizens must be present and actively participate in public meetings from the initial goals and objectives setting stage to the final stage of articulating community priorities in the five year action plan.

The planner must strive to involve the public early in the process. A single open space or recreation issue, e.g. rapid town-wide growth in the Town of Hudson, may serve to unify support in the community for a planning initiative. 
The planner should meet with persons involved in community recreation activities and spend time observing open space areas and recreation facilities. By seeking out persons or organizations that may provide insights into local open space and recreation demand, or know the history of prior planning efforts, the planner may identify issues that may be of asslstance in solidifying community support for a new or up-dated plan.

In conclusion, it must be stressed that planning for open space and recreation is as much an education process in the value of natural resources as it is an inventory of existing conditions, and quantification of future need. The creation of a public awareness of the value of open space as a finite resource is as much the planner's charge as is a written report. So too, must the planner convey the importance of, and need for, a safe and healthy park and playground environment where persons of all ages may particlpate in both passive and active leisure pursuits.

Involvement of the community's residents in decision making and priority setting activities is a prerequisite for a successful plan. The public meeting is the primary forum in which public awareness may be fostered, concerns voiced and information exchanged. Indeed, without public 
participation the process becomes one in which planners may not be working toward community goals, but rather to satisfy bureaucratic mandates.

The issues of outdated data and the universal applicability of accepted open space and recreation planning standards remain difficult to resolve. Where fiscal constraints in the community prohibit collection of current demographic and socio-economic data, existing data must be used. However, in communities where budgetary constraints do not preclude labor intensive and often costly collection of current data, information gathering may be conducted in confunction with other potential data users.

The need to conserve natural resources and protect open spaces becomes more urgent as the remaining undeveloped land in the rapidly developing community faces increasing development pressure. Land is a finite resource and as such the time to preserve open space is before it is gone. With land values in Massachusetts skyrocketing, public acquisition of open space will become more difficult as acquisition costs $r$ ise and the inventory of available land is reduced. However, funding is critical; the community, the state and the federal government must be willing to make the financial commitment to acquire open space. Land that may be affordable for the community to acquire today may be beyond the public means tomorrow. 
While acquisition of additional open space, parks or other recreational facilities is a priority in many cities and towns, existing facilities should not be allowed to suffer from a lack of upkeep because maintenance funds have been spent elsewhere. The community's existing facilities must be granted a priority in budgetary allocations. The creation of both long range malntenance and acquisition programs to establish a balanced approach to current and future community needs may be a means to resolve potential budget conflicts.

It is hoped that by providing a review and critique of the existing open space and Recreation Planning process in the Commonwealth of Massachusetts, a contribution to the process has been made. 
APPENDI $X$

$-60-$ 
DEFINITIONS

$-61-$ 
Accepted standards - speciflc set of criterla used to define open space and recreation need in a community. Usually population based, standards may also include geographic service areas and generally involve a suggested site size for each activity or population served.

Aquifer - A naturally occurring layer of porous rock where ground water has gathered and is held. The aquifer is the result of surface water that has percolated through overlying layers of soll to saturate underlying layers of porous rock and often yields significant quantities of potable water. Collected over a long period of time, this valuable resource is easily polluted and should be zealously protected.

Active Recreation - An event, sport or game that requires the participant to engage in a deliberate effort. Basketball, jogging, skilng and tennis are several examples.

Community Park - A community park should be designed to serve the active and passive recreational needs of a population of approximately 15,000 to 20,000 persons. Composed of an area between 20 to 50 acres, the community park should contain an athletic field, a playground, tennis 
or basketball courts and an area for passive recreation. The community park may also contain a special facility such as a swimming pool or driving range.

Ground Water - Water resources contained in fully saturated portion of an aquifer.

Major Park - A community should have one major or large urban park per 40,000 to 50,000 persons. The major park should be a minimum of 100 acres in size and contain ample facilities to host clty-wide events. Athletic fields, tennis and basketball courts, picnlc areas, walking or jogging trails should present. Speclal facilities may also be included.

Neighborhood Park - The neighborhood park may range in size from a minimum of 5 acres up to 20 acres and should serve users of every age. Included should be an athletic field, basketball or tennis courts and a landscaped area for passive recreation serving a population between 2,000 and 5,000 people.

Open space - Perhaps no term connotes a greater variety of mental images or has such disparate meanings as does "open space". Generally thought of as a recreation resource, open 
space may also be used as privacy barrier or as an area in which to conserve or protect natural resources. Open space may range in size from a small grass buffer separating a parking area or street from housing units in urban or suburban communities, to expansive undeveloped land holdings in rural communities. Ownership of open space areas falls into three general categories; public, semi-public and private. Publicly owned open space may include watersheds, reservations or national and municipal parks. Semi-public open space may broadly be defined as land owned by a group of persons for their common use. Privately owned open space may range in size from a balcony in a multiEamily development, to thousands of acres of woodland owned by large paper or pulp producing corporations.

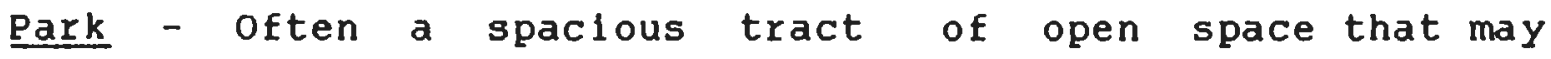
combine lawns, wooded or wilderness areas and frequently provides opportunity for active recreation. However, a park may range in size from several thousand square feet in an urban area, e.g. a reclalmed vacant lot, to several hundred square miles, e.g. Glacier or Yellowstone National Parks.

Passive Recreation - Walking, birdwatching or sitting on a bench in the park are several examples of passive recreational pursuits conducted outdoors. 
playground - Usually located at or near an elementary school, a playground provides outdoor recreation space for children between the ages of 5 and 12 years. Ranging in size from 3 to 8 acres, the playground should have separate areas for fleld games, playground equipment, a playlot for preschool children and an area for quiet games or crafts.

Playlot - playlots are most often found in urban areas or adjacent to multi-family housing. A playlot may range in size from 2,500 square feet to 1 acre. Located within 300 to 400 feet of housing units they serve, the playlot should be designed for users up to age six. Swings, slides and other similar playground equipment should be available.

Reglonal Park - Frequently comprising an area of 250 acres or more, a regional park may fulfill all the recreational needs of a smaller community. Active and passive recreation opportunities in the regional park may attract visitors from adjacent communities.

Surface water - water resources located on earth's surface. For example, reservoirs, rivers, lakes, steams and brooks. 


\section{BI BL I OCRAPHY}

Bannon, Joseph J., Leisure Resources: Its Comprehensive Planning, Englewood Cliffs, New Jersey, Prentice-Hall, 1976

Bartenstein, Fred, "The Future of Urban Forestry", Washington, D.C., U.S. Department of Agriculture, Forest Service, 1980

Braiterman, Marta, et al., "The Agricultural Land Resource Base of Massachusetts", Massachusetts Agricultural Experiment station, University of Massachusetts, Amherst, Massachusetts, 1976

Buechner, Robert D. ed., National Park, Recreation and Open Space Standards, National Recreation and Park Association, Washington, D.C., June, 1971

Canter, Larry $\boldsymbol{~}$. , et al, Impact of Growth A Guide for soc 10Economic Impact Assessment and Planning, Chelsea, Michigan, Lewis Publishers, 1985 


\section{BI BL I OORAPHY}

Commonwealth of Massachusetts, Memorandum, "Guidelines for Criteria of Urban Self-Help Regional and statewide Facilities", William Lister, Executive office of Environmental Affairs, Boston, Massachusetts, August, 1985

Commonwealth of Massachusetts, "Open space Programs", Executive office of Environmental Affairs, Boston, Massachusetts, January, 1987

Commonwealth of Massachusetts, "Planning Requirements For The Federal Land and water Conservation Fund and The Massachusetts Self-Help Programs", Division of Conservation Services, Boston, Massachusetts, September, 1984

Commonwealth of Massachusetts, office of the Inspector General, "Report on The Metropolitan District Commission: The Parks Division and Central Management systems", Boston, Massachusetts, september, 1983 


\section{BI BL I OGRAPHY}

De Chaira, Joseph and Koppelman, Lee E., Time-Saver standards For Site Planning, McGraw-Hill Book Company, New York, New York, 1984

De Chaira, Joseph and Koppelman, Lee E., et.al., planning Design Criteria, Van Nostrand Reinhold Company, New York, New York, 1969

Field, Herman H., PhD., AICP, "Why Open space And Recreation Plans?", Massachusetts Association of Conservation Commissions, Lincoln Filene Center, Tufts University, Medford, Massachusetts

Heckscher, August and Robinson, Phyllis, open spaces the Life of American Cities, Harper and Row, New York, New York, 1977 


\section{BI BL I OORAPHY}

Lerner, Joel, "Open Space And Recreation Plans: The state Agency's Role", Massachusetts Association of Conservation Commissions, Lincoln Filene Center, Tufts University, Medford, Massachusetts

Lima, Alfred J., "Preparing An Open space And Recreation Master Plan", Massachusetts Association of Conservation Commissions, Lincoln Filene Center, Tufts University, Medford, Massachusetts

MacConnell, william P., "Remote sensing 20 Years of Change in Massachusetts 1951/52-1971/72", Research Bulletin Number 630, Massachusetts Agricultural Experiment station, University of Massachusetts, Amherst, Massachusetts, November, 1975 


\section{BI BL IOGRAPHY}

MacConnell, William P., "Land Use Update", Research Bulletin Number 686, Massachusetts Agricultural Experiment station, University of Massachusetts, Amherst, Massachusetts, February, 1984

MacConnell, William P., "Land Use Update", Research Bulletin Number 702, Massachusetts Agricultural Experiment station, University of Massachusetts, Amherst, Massachusetts, May, 1985

McKeever, Ross J., Editor, The Community Builders Handbook, Urban Land Institute, Urban Land Institute, Washington, D.C., 1968

Metropolitan Area Planning Council, "Conflicting And Compatible Land Uses In The Magic Subregion, A Status Report", Metropolitan Area Planning Council, Boston, Massachusetts, May 1, 1987 


\section{BI BL IOGRAPHY}

Metropolitan Area Planning Council, Guidelines: Recreation Conservation, Guldelines to Assist Municipalities in Preparing Conservation and Recreation plans, Metropolitan Area Planning Council, Boston, Massachusetts, 1977

Metropolitan Area Planning Council, "Transreport", Volume IV Number 1, Fall, 1987, Metropolitan Area Planning Council, Boston, Massachusetts, 1987

National Recreation and Park Association, Recreation, Park, and Open Space Standards and Guidelines, National Recreation and Park Association, Washington, D.C., 1983

U.S. Department of Agriculture, soll Conservation service, "Citizens" Handbook of Farmland Retention Techniques for Massachusetts", prepared in cooperation with the Hampden, Hampshire, and Franklin Conservation Districts and Massachusetts Department of Food and Agriculture, March, 1982 


\section{BI BL IOCRAPHY}

U.S. Department of Agriculture, Soil Conservation Service, "Massachusetts Soll \& Water Conservation", Amherst, Massachusetts, February, 1985

U.S. Department of Agriculture, soll Conservation service, "National Agriculture and Land Evaluation Handbook", Washington, D.C., January, 1983

U.s. Department of the Army, Headquarters, Planning and Design of Outdoor Recreation Facilities, Washington, D.C., 1975

U.S. Department of Housing and Urban Development, prepared by Public Technology, Inc. "Leisure Services Location Package: Project Operations Guide", Office of Policy Development and Research, Washington, D.C., 1978 


\section{BI BL I OGRAPHY}

U.S. Department of the Interior, prepared by Urban Research and Development Corporation, Handbook for Recreation and Planning, no date

spirn, Anne Whiston, The Granite Garden, Urban Nature and Human Design, Basic Books, Inc., New York, New York, 1984

Thomas Planning Services, Inc., "City of Chelsea open space And Recreation Master Plan", Thomas planning services, Inc., Boston, Massachusetts, June, 1987

Thomas Planning Services, Inc., "Town of Hudson Open space And Recreation Master Plan", Thomas Planning Services, Inc., Boston, Massachusetts, August, 1987

Randall, William E., PhD., "Defination of "Regional and "statewide" As Terms Used In The 1984 Admendment To The Urban Self-Help Act", University of Massachusetts, Amherst, Massachusetts, March, 1985 
SUPPORT DOCUMENT 


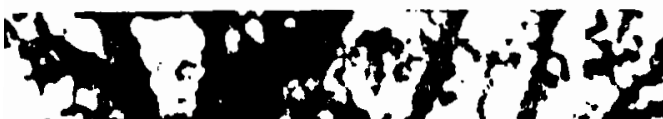

+35.

s.t.

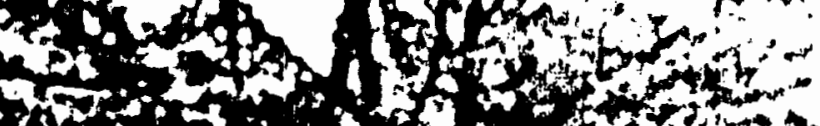

$\infty$

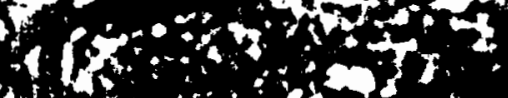

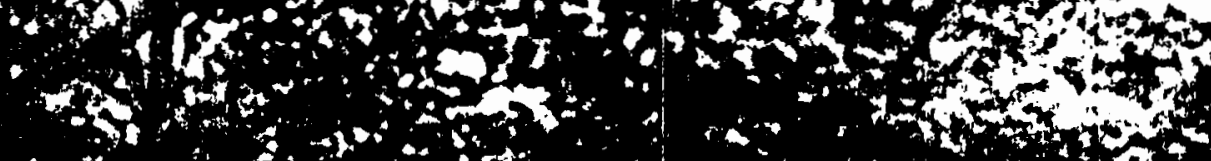

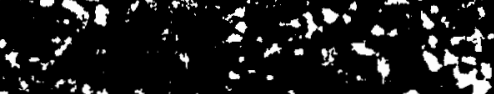

$+6$

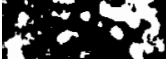
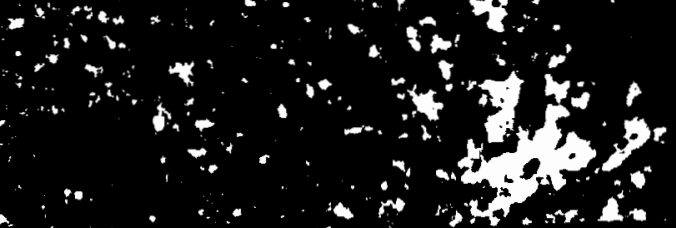

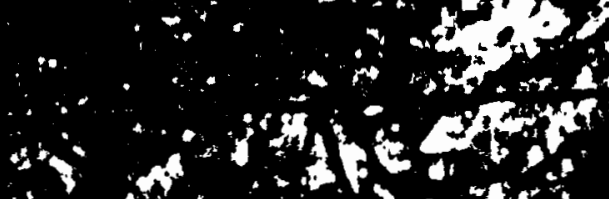

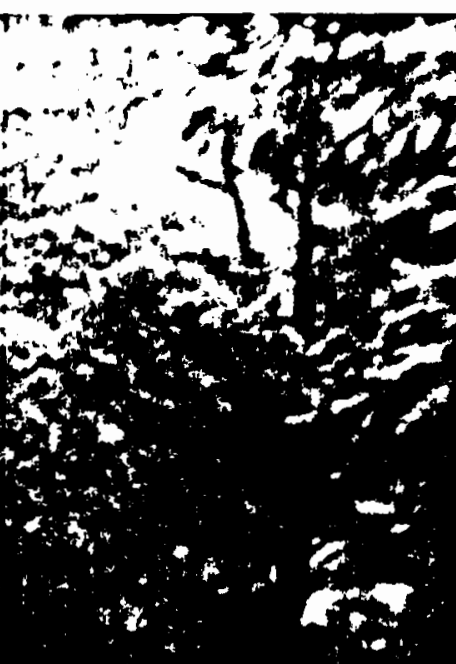

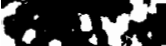

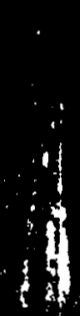

(a)

tow

$+2 x^{2}+4$

$\gamma$

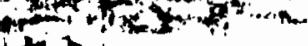

\section{1}

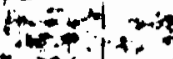

1.

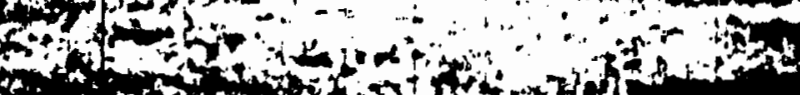

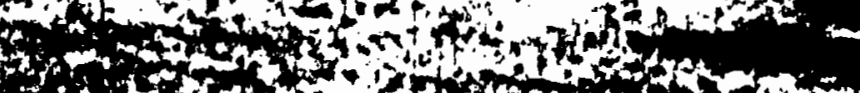

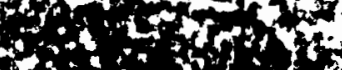

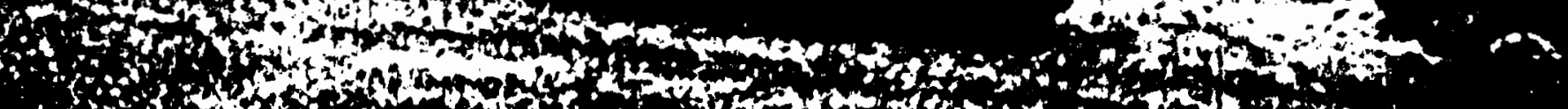

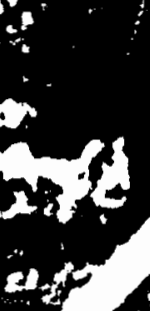

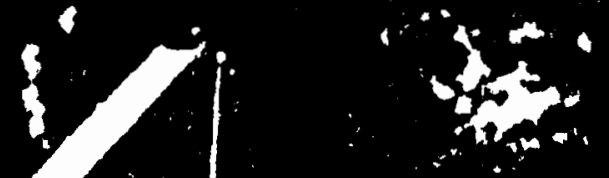

$-$

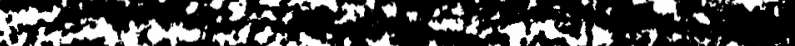

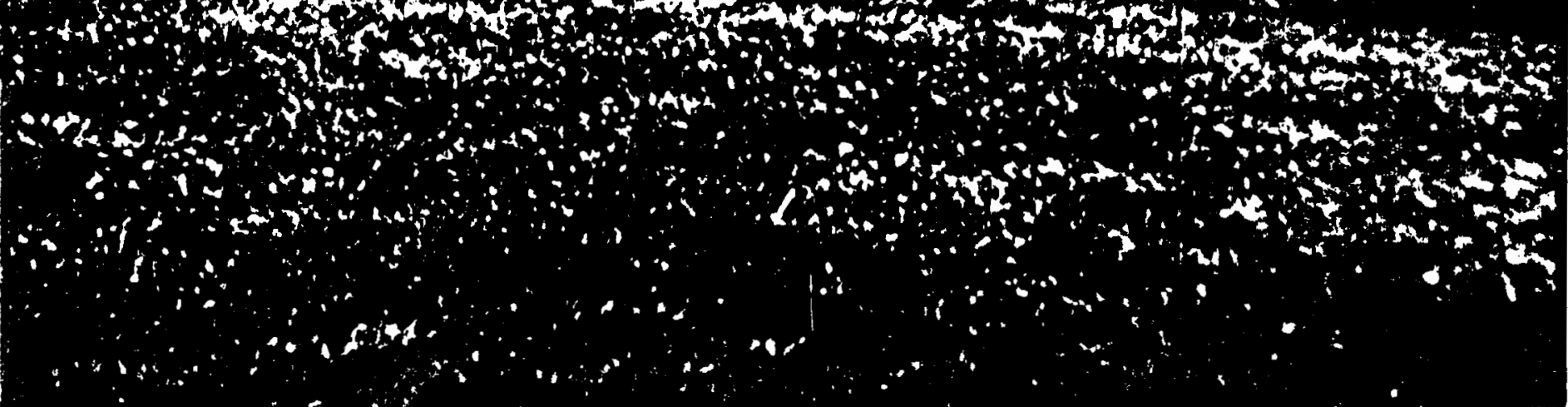

TOWN OF HUDSON

OPEN SPACE AND RECREATION MASTER PLAN

AUGUST 1987

THOMAS PLANNING SERVICES, INC.

120 TREMONT STREET

BOSTON, MASSACHUSETTS 


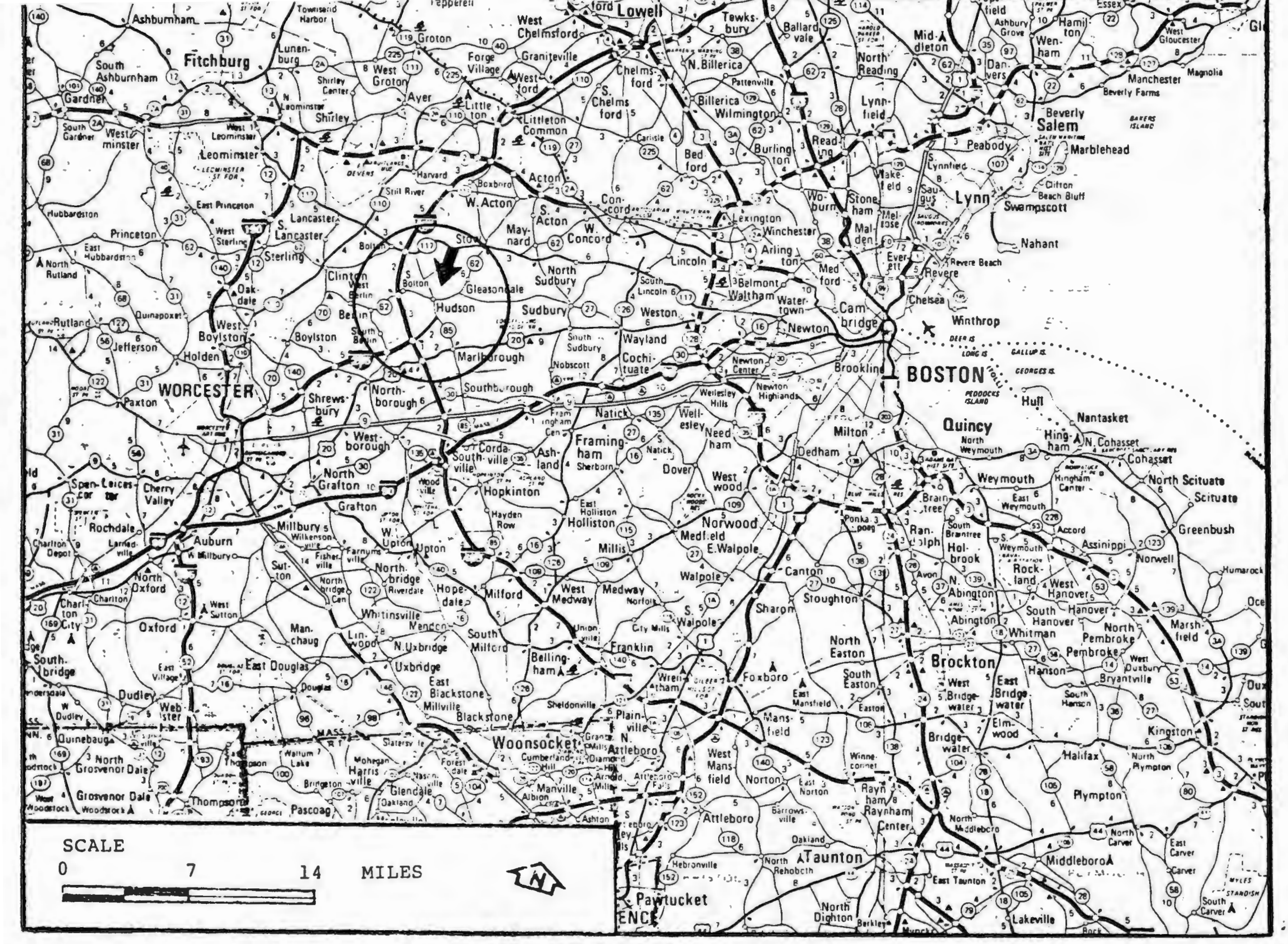


TABLE OP CONTENTS

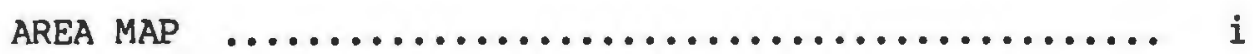

FACILITIES MAP $\ldots \ldots \ldots \ldots \ldots \ldots \ldots \ldots \ldots \ldots \ldots$ ii

TABLE OF CONTENTS $\ldots \ldots \ldots \ldots \ldots \ldots \ldots \ldots \ldots \ldots$...............

INTRODUCTION $\quad \ldots \ldots \ldots \ldots \ldots \ldots \ldots \ldots \ldots \ldots \ldots \ldots \ldots \ldots$

BACKGROUND INFORMATION $\ldots \ldots \ldots \ldots \ldots \ldots \ldots \ldots \ldots \ldots \ldots$

STUDY METHODOLOGY $\ldots \ldots \ldots \ldots \ldots \ldots \ldots \ldots \ldots \ldots \ldots \ldots \ldots$

GOALS ANALYSIS $\ldots \ldots \ldots \ldots \ldots \ldots \ldots \ldots \ldots \ldots \ldots \ldots \ldots$

FACILITIES INSPECTIONS $\ldots \ldots \ldots \ldots \ldots \ldots \ldots \ldots \ldots \ldots \ldots$

OPEN SPACE AND RECREATION INVENTORY $\ldots \ldots \ldots \ldots \ldots \ldots \ldots . . .14$

SUMMARY OF OPEN SPACE AND RECREATION SITES $\ldots \ldots \ldots \ldots . . .25$

OPEN SPACE AND RECREATIONAL NEED $\ldots \ldots \ldots \ldots \ldots \ldots \ldots$

OPEN SPACE AND RECREATION PLAN RECOMMENDATIONS $\ldots . . .40$

FIVE YEAR ACTION PLAN $\ldots \ldots \ldots \ldots \ldots \ldots \ldots \ldots \ldots \ldots \ldots$

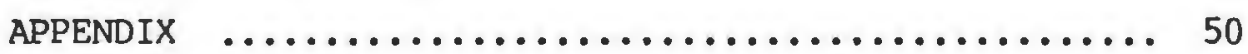




\section{INTRODUCTION}

The purpose of this study is three-fold; first, this study is to revise and update of the 1976 Hudson Open Space and Recreation Study; second, the study seeks to promote a continuing awareness of the value of open space and recreation and third, the study serves as a basis for a continued program to improve the quality of life. The study consists of seven parts: background information including population, social and economic characteristics for Hudson; a goals and objectives statement for the plan; an inventory of public, quasi-public and private, but used by the public, open space or recreation facilities; an analysis of community open space or recreation need; a five-year action plan; a methodology and statement of agency participation; and upon completion written comments from the Planning Board and the regional planning agency.

Open space plays a vital role in a community. Permanent open space may preserve a portion of a town's natural features that may lend the town its character, create an identity, or establish a link to a more pastoral time. open space can provide a habitat for local or transient wildlife populations, protect groundwater resources, define neighborhoods, integrate land uses, or act as a buffer between noncompatible land uses. Finally, open space allows the natural environment to exist along side the built environment, providing a refuge where passive recreational pursuits ease the stress of daily life. Recreational sites serve to accommodate a community's need to engage in leisure activities, organized sporting events or follow individual physical fitness programs in a safe and healthy environment. Active recreation has become an important part of American culture, with increased leisure time and the desire by many to lead a more healthy life combining to create a heightened demand for recreational services in the community.

\section{BACRGROOND INFORMATTON}

\section{LOCATION}

The Town of Hudson, comprising a total of 11.81 square miles, is located 18 miles east of Worcester and 28 miles west of Boston in the east/central portion of the Commonwealth. Bisected by the Assabet River, the Town has undulating topographic features, a myriad of wetlands and steams and a decidely suburban and small town character. Hudson shares borders with five other communities in the vicinity of Routes 495 and 128. The Towns of Bolton and stow lie to the north, the City of Marlborough to the south, Sudbury to the east and Berlin to the west.

Like many Massachusetts communities enjoying close proximity to major employment centers, Hudson faces intense development pressure. As demand for residential, commercial and industrial development sites increases, attention must be paid to the preservation of the community's natural resources. The Town's open spaces and recreational facilities must be protected and maintained in order to provide adequate passive and active recreational opportunities to an expanded resident population and preserve important natural resources for future generations. 
TOPOGRAPHY/LAND USE

Hudson's topography is typical of that found throughout the glaciated New England countryside. Characterized by rolling hills, low lying swamps and wetlands as well ais many water bodies, the landscape is wonderfully varied and offers many good view lines from hilltop locations. The Assabet River winds its way from north to south dividing the Town in half, and passing through the downtown business district. A narrow floodplain adjacent to the river affords one of the relatively few level areas in Town and is the location of one of the Town's most attractive parks.

Traditionally, Hudson has been a community centered around manufacturing. Until the demise of local mills, manufacturing facilities had generally been located in the center of Town, near the river. Table I, below, identifies land use in Hudson.

TABLE I

HUDSON LAND USE 1971 - 1985

(In acres)

\begin{tabular}{|c|c|c|c|c|c|c|}
\hline $\begin{array}{l}\text { YEAR } \\
\text { CATEGORY }\end{array}$ & $\begin{array}{l}1971 \\
\text { acres }\end{array}$ & $\begin{array}{r}1980 \\
\text { acres }\end{array}$ & $\begin{array}{r}1985 \\
\text { acres }\end{array}$ & $\begin{array}{l}71-80 \\
\text { percent } \\
\text { change }\end{array}$ & $\begin{array}{l}80-85 \\
\text { percent } \\
\text { change }\end{array}$ & $\begin{array}{l}71-85 \\
\text { percent } \\
\text { change }\end{array}$ \\
\hline Residential & 2,097 & 2,218 & 2,334 & 68 & 58 & 118 \\
\hline Commercial & 162 & 203 & 225 & 258 & $118^{\circ}$ & 398 \\
\hline Industrial & 132 & 233 & 245 & $77 \%$ & 58 & 868 \\
\hline Transportation & $\frac{58}{2,449}$ & $\frac{81}{2,735}$ & $\frac{81}{2,885}$ & $\frac{408}{128}$ & $\frac{-}{58}$ & $\frac{408}{188}$ \\
\hline $\begin{array}{l}\text { Urban Open Space } \\
\text { Open Areas }\end{array}$ & $\begin{array}{l}154 \\
169 \\
323\end{array}$ & $\begin{array}{r}173 \\
86 \\
259\end{array}$ & $\begin{array}{r}166 \\
155 \\
321\end{array}$ & $\begin{array}{r}128 \\
-498 \\
-208\end{array}$ & $\begin{array}{r}-48 \\
808 \\
248\end{array}$ & $\begin{array}{r}88 \\
-\quad 88 \\
-18\end{array}$ \\
\hline Agriculture & 615 & 561 & 459 & -98 & -188 & -258 \\
\hline Forest & 3,482 & 3,346 & 3,227 & -48 & -48 & -78 \\
\hline Wetlands & 574 & 567 & 565 & -18 & - & -28 \\
\hline Outdoor Recreation & 45 & 45 & 45 & - & - & - \\
\hline Mining & 136 & 111 & 121 & -188 & 98 & -118 \\
\hline Waste Disposal & $\frac{56}{4,908}$ & $\frac{56}{4,686}$ & $\frac{57}{4,474}$ & $-\frac{-}{58}$ & $-\frac{28}{58}$ & $-\frac{28}{-98}$ \\
\hline
\end{tabular}

TOTAL $\quad 7,680 \quad 7,680 \quad 7,680$

Source: MacConnell Land Use Study 1985

Conflicting and Compatible Land Uses and Intensities in the MAGIC Subregion, Metropolitan Area Planning Council, May 1, 1987 
Many land holdings adjacent to the Assabet are presently underutilized and fail to take full advantage of their riverside location. Modern industrial land uses, no longer attracted by water as a source of power, are now attracted to Hudson for other reasons. The presence of Interstate 495 and the Town's proximity to the Route 128 beltline appear to have replaced the Assabet River as a factor in location decisions. The downtown Hudson business district contains many turn of the century three and four story buildings of historic significance. Retail and commercial land uses once attracted by a concentrated local workforce remain in the downtown area, with only limited strip commercial development occurring along roadways entering the Town. Residential land use is predominately single family housing units, with a mixture of two and three-family housing units and recently constructed condominiums.

\section{POPULATION}

Hudson's 1986 population of 17,523 persons is an increase of eighty-one percent since 1960 according to the Office of the secretary of the Commonwealth and U.S. Census data, yielding a current density of 1,484 persons per square mile. The Town's population grew rapidly in the early 1960s' and 1970s'; however, the rate of growth has slowed considerably during the 1980''. Table II, below, displays Hudson's population at five year increments.

According to the U.S. Census, the median age of Hudson residents had risen by almost four years between 1970 and 1980. In 1970 the median age was 25.5 years old, ten years later the median age was 29.2 years. Significant changes also occurred between 1970 and 1980 in the under eighteen and over sixty-five age cohorts. The number of persons over age sixty-five increased by a dramatic eighty-eighty percent. The number of persons under the age of eighteen grew by fourteen percent during the same lime period.

TABLE II

HUDSON POPULATION 1960-1986

$\begin{array}{lccc}\text { YEAR } & \text { POPULATION } & \text { POPULATION CHANGE } & \text { PERCENT CHANGE } \\ 1960 & 9,666 & - & - \\ 1965 & 13,642 & +3,976 & +41.138 \\ 1970 & 16,084 & +2,442 & +17.908 \\ 1975 & 16,827 & +743 & +4.618 \\ 1980 & 16,408 & -419 & -2.498 \\ 1986 & 17,523 & +1,115 & +6.798 \\ 1960-1980 & -- & +7,857 & +81.288\end{array}$

Source: 1970 U.S. Census, 1980 U.S. Census

Commonwealth of Massachusetts, Office of Secretary 
Recreational need and demand may also be affected by income level. Median family income or per capita income of a community is often used as a gauge in ascertaining the degree to which members of that community are able to purchase recreational services. In general, members of a community that has a high median income may be bettnr able to purchase additional rerreational services offered by the private sector. The U.S. Census stated that in 1979 Hudson's median family income was $\$ 24,456$, approximately 1108 higher than median family income recorded in the 1970 Census. Hudson's 1979 median family income exceeded national $(\$ 21,023)$, state $(\$ 21,166)$ and county $(\$ 20,335) 1979$ median income levels by sixteen percent, fifteen percent and twinty percent respectively.

While Hudson's total population has been increasing steadily for the past two decades, public school enrollment has recently declined. According to enrollment figures supplied by the Hudson School Department, between 1980 and 1986 public school enrollment decreased by 542 students, or approximately eighteen percent, see Table III, see appendix for enrollment by grade and school. Changes in age distribution will affect the type and amount of open space needed and recreation demand.

TABLE III

HUDSON PUBLIC SCHOOL ENROLLMENT 1980-1986

$\begin{array}{lll}\text { YEAR ENROLLMENT NUMBER CHANGE } & \text { PERCENT CHANGE }\end{array}$

$1980 \quad 2,909$

1981

2,721

$-188$

$-6.468$

1982

2,575

$-146$

$-5.368$

1983

2,565

$-10$

$-.388$

1984

2,484

$-81$

$-3.158$

1985

2,435

$-49$

$-1.978$

1986

2,367

$-68$

$-2.798$

1980-1986

$-542$

$-18.638$

Source: Hudson School Department

Enrollment Chart, recorded October 1, annually

As the character of community's population changes through aging and growth, open space and recreational needs and demands in the community also change. In 1986, the Town's Division of Recreation offered more than thirty recreational programs and fifteen special events aimed at all age groups in response to increased and varied demand. Current use of recreational facilities by Town residents and employees of local corporations, especially the Hudson High school gymnasium, is very high. High participation rates in programs sponsored by the Division of Recreation also signify extensive demand placed upon existing facilities. 
The Town of Hudson's proximity to regional transportation routes has been one of the primary reasons for the community's rapid growth. Interstate Route 495 passes through the southwest corner of the Town providing north/south automobile and truck access to regional markets and employment centers. Drawn by good access to the interstate several high technology corporations have chosen to locate in the southwest portion of Hudson. State Routes 62 anci 85 link Hudson to the surrounding Towns of Berlin, Clinton, and Stow and the City of Marlborough.

The local road system of minor, collector and arterial streets is well established and maintained. Hudson's road system comprises approximately eighty miles of public throughways. Many roads are classified as county roads, having been constructed and maintained under Chapter 90 provisions. The absence of a local mass transportation system increases the public dependence on personal transportation as a means of circulation.

WATER SUPPLY AND SEWAGE DISPOSAL SYSTEMS

Potable water is supplied to approximately ninety to ninety-five percent of community residents from a network of Town owned wells and storage facilities. Four wells, Chestnut Street Well, Cranberry Well, Kane Well and Rimkus Well, and one surface storage area, Gates Pond, supplied hudson residents with $810,770,760$ gallons of water in 1985. Average daily per capita water consumption for 1985 was approximately 127 gallons. A total of ninety-seven miles of water mains, ranging in size from six inches to twenty inches in diameter, run beneath Town streets linking water users to Town supplies. The Town has recently completed the installation of a new twelve inch water main to improve flow in the cox street area. The Department of Public Works has recently expanded the area serviced by its water system to include the Town's southern portion. Several water towers, situated at various locations throughout the Town, are used to retain a ready supply of water and to maintain a desired level of water pressure. Pressure ranges from a high of seventy pounds pressure per square inch aiong Main street to a low of twenty pounds pressure per square inch in the higher elevations along Hickory and Chapin roads. The construction of a proposed watertank to be located in the Hickory/Chapin Road area, and extension of a water main from Technology Drive to the proposed watertank will improve water flow and pressure to that service area. Hudson has been successful in acquiring property adjacent to several of its well sites as part of an nngoing commitment to aquifer protection.

The Town owns and maintains an expanded and upgraded facility for the disposal of raw sewage. The sewage treatment plant located on cox street, adjacent to the Department of Public Works building, has a minimum design capacity of 2.63 million gallons of sewage per day. Processing an average of 2.2 million gallons per day, the facility treats approximately $66,000,000$ gallons of sewage per month. According to a spokesperson at the Hudson Department of Public Works, the system is currently at ninety-five percent capacity. Inclement weather experienced in spring storms recently forced the plant to handle between four and six million gallons per day. Infiltration of groundwater into the system has also created capacity problems for the system, the Department of Public Works is working with a consultant on a grant application to study the infiltration problem. 
The community profile of Hudson presented under Background Information was created for the purpose of observing demographic, economic and land use trends in Hudson. Information was garnered from existing planning reports, U.S. Census data, the Hudson Monograph and various Town reports. A review of municipal services and the extent and condition of the existing Town infrastructure comprises a portion of the profile.

Data relating to condition and use of recreation sites and open space areas was gathered from several sources. Facilities and sites were each visited on several occasions. Site visits yielded information about the condition of playing surfaces and equipment, type of activity the site encourages, and type of adjacent land uses. Various Town departments assisted in the data gathering process by providing additional information concerning each site. The Assessor's Office of the Town of Hudson provided information on the size and location of open space and recreation areas. Division of Recreation programing brochures, materials and records were reviewed to identify the nature, scope and participation levels in Town sponsored recreational programing, and school enrollment figures were obtained from the office of the Superintendent. The Department of Public Works supplied information related to Hudson's infrastructure.

A literature search was conductad to review prior planning and engineering reports dealing with land use issues in Hudson. When appropriate, goals identified in other relevant planning documents were incorporated with current open space and recreation goals to promote comprehensive planning. Accepted recreation and open space planning standards were examined in determining the most appropriate type, size and distribution of open space areas and recreational facilities in Hudson.

An open space and recreation needs analysis based on existing conditions and accepted planning standards was used to identify current needs and demands. Projection of future Town-wide and neighborhood oriented open space and recreation needs and demands followed.

Public meetings were held to identify rela: i open space and recreation issues, needs and concerns. Study findings were presented for comment. Public discussion of current and previous planning goa 1 s and efforts was promoted to stimulate consensus building.

Statement of Agency Participation

The local agencies and citizen groups listed below participated in developing this Open space and Recreation Master Plan. In addition, Hudson's crncerned citizens and members of the following organizations played a vital role in formulating proposed open space and recreation goals and priorities, indentifying recreation needs and providing background information and data.

Town of Hudson

Division of Recreation

Conservation Commission

Department of Public Works

Parks Commission

school Department

Digital Equipment corporation

Hudson Elderly Services 
one of the purposes of a goals and objectives statement is to facilitate public understanding of, and participation in, the planning process. A clear statement of desired long-term pu. oses and short-range actions provide a framework for community decision making. The goals and objectives statement also serves the purpose of providing an element of stability, consistency and direction in Town actions affecting open space and recreation.

The following goals and objectives identified in the Town of Hudson Municipal Recreation and Open Space Study of April 1976, are restated below. As part of public involvement in the planning process, these goals were reviewed, and modified.

OPEN SPACE 1976

\section{GOALS}

1. Establish a balance between development and open space.

2. Maintain or improve the natural envi ronment.

3. Protect the Town water supply.

4. Establish aciequate areas for enjoyment of the natural envi ronment.

5. Maximize the open space and recreation opportunities, particularly by providing connectors with adjacent public and private holdings.

6. Maintain man-made features which enhance the environment.

\section{OBJECTIVES}

Quantify open space needs and values.

Re-use sanitary land fill site. Maintain use of agricultural land.

Protect wells, streams and ground water supply.

Acquire areas with distinctive natural features.

Establish buffers between areas of differing land use.

\section{POLICIES}

Use methods other than purchase, where possible to acquire open land.

Protect and preserve unique natural areas. Preserve scenic views, historic areas, out-crops and swamp land.

Use methods other than purchase when possible to protast the water supply.

Acquisition consistent with neighboring towns.

Encourage passive use of open space lands. Preserve a variety of open space lands.
Preserve historical areas.
Use methods other than purchase.

1. Town of Hudson Municipal Recreation and Open Space, Thomas Planning Associates, a Division of Universal Engineer ing Corporation, 100 Boylston Street, Boston, Massachusetts, April 1976 
GOALS

1. Provide a widerange of recreation facilities and programs which can be available to every resident of the Town.

2. Provide for constructive use of leisure time.

3. Intensify use of existing facilities where appropriate.

4. Bring existing facilities to standard.

5. Provide recreation areas in sections without facilities.

6. Encourage multiple use of properties.

7. Utilize land use patterns which enhance open space and recreation.
OBJECTIVES

Expand activities

at a consistent and conomical rate, e.g. additiona $\perp$ playground programs and additional adult activities at existing sites.

Increase and develop skills in active and passive recreation.

Upgrade equipment at facilities to increase use. Tmprove circulation and access from various purts of the Town.

Immediate attention to facilities in the highest density portion of the Town.

Provide recreation areas and facilities in areas of need.

Provide for passive recreation on conuirvation and other Town lands.

Provide for PUD and cluster zoning.

\section{POLICIES}

Around-the-clock

use of recreation

facilities.

Reasonable cost. Readily accessible facilities.

Provide educational leisure time activities. Base activities on interests of citizens.

Maximize present investment.

Protect and minimize present investment.

Use measures other than purchase when possible, such as dedication, zoning.

:aximize use of present and future areas and facilities.

Use innovative land use controls. 
GOALS RELATED TO RECREATION AND/OR OPEN SPACE 1976

GOALS

1. Create linkages.

2. Enhance urban design.

3. Balanced neighborhood facilities.

4. Minimize impact on tax rate.
OBUECTIVES

Development a plan of linkages.

Establish design guidelines.

Serve all neighborhoods with a full range of municipal facilities.

Design facilities to minimize maintenance.
POLICIES

Use methods other than purchase when appropriate. Establi.sh muitiple purpose linkages when appropriate.

Use methods other than purchase when appropriate.

Multiple use of areas and facilities where appropriate.

Utilize appropriate federal and state programs. Schedule expenditures so that they are not impacting the rate.

\section{PROPOSED 1987 JPEN SPACE AND RECREATION GOALS AND OBJECTIVES}

The goals and objectives identified in the 1976 open Space and Recreation Plan, with minor irdification, should be carried over to the 1987 open Spare and Recreation Plan. In addition, several new goals and objectives are proposed for inclusion in the updated Plan. Listed below are the proposed modifications and additions to the 1976 Goals statement (additions underlined, deletions lined.)

GOALS

OPEN SPACE

2. Maintain or improve the natural envi ronment.

5. Maximize the open space and recreation opportunities, particularly by providing comnectors with adjacent public and private holdings.

OBUECTIVES

POLICIES

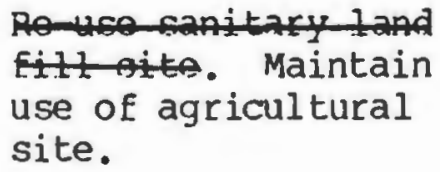

Rousenanitacy tand filt Maintain use of agricultural site.

Establish buffers between areas of differing land use.
Protect and preserve unique natural areas. Preserve scenic views, historic areas, out-crops and wetlands.

Encourage passive use of open space lands. Preserve a variety of open space lands. Link this goal to re-use proposals contained in Reuse Feasibility study MBTA Right-of-Way: Marlborough Branch Line 
RECREATION

1. Provide a widerange of recreation facilities and programs which can be available to every member of the Town.
Expand activities

at a consistent and economical rate, e.g. ar.":ional playground programs and additional adult activities at existing sites. Build sports complex housing year-round activities.

GOALS RELATED TO RECREATION AND/OR OPEN SPACE

Cins

5. Cont inue high quality service delivery of open space and recreation goportunities.
OBJECIIVES

Create long-range maintenance plan for all open space and recreation sites.
Around-the-clock use of recreation facilities. Reasonable cost. Readily accessible facilities.
POLICIES

Reduce maintenance cost. Assure that all facilities receive equal maintenance.

Therefore, the 1987 Goals Statement reads as follows:

OPEN SPACE 1987

\section{GOALS}

1. Establish a balance between development and open space.

2. Maintain or improve the natural

envi ronment.

3. Protect the Town water supin' $\gamma$.

4. Establish adequate areas for enjoyment of the natural envi ronment.
OBUECTIVES

Quantify open space needs and values.

Maintain use of agricultural 1 and.

Fiutect wells, streams and ground water supply.

Acquire areas with distinctive natural features.
POLICIES

Use methods other than purchase, where possible to acqui re open land.

Protect and preserve unique natural areas. Preserve scenic views, historic areas, out-crops and wetlands.

Use methods other than purc: ase when possible to protect the water supply.

Acquisition consistent with neighbor ing towns. 
5. Mailinize the open space and recreation opportunities, particularly by providing connectors with adjacent public and private holdings.

6. Maintain man-made features which enhance the envi ronment.

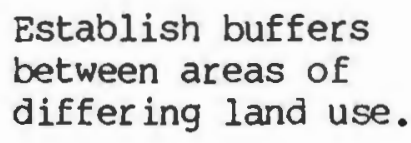

Establish buffers between areas of differing land use.

Preserve historical areas.

OBJECTIVES

Expand activities at a consistunt and economical rate, e.g. additional playground programs and additional adult activities at existing sites. Build sports complex housing year-round activities.

Increase and develop skills in active and passive recreation.

Upgrade equipment at faciilties to increase use. Improve ci rculation and access from various parts of the Town.

Immediate attention to facilities in the highest density portion of the Town.

Provide recreation areas and facilities in areas of need.
Fncourage passive use of open space lands. Preserve a variety of open space lands. Link this goal to re-use proposals contained in Reuse Feasibility Study MBTA Right-of-Way; Marlborough Branch Line.

Use methods other than purchase.
POLICIES

Around-the-clock use of rezreation facilities. Reasonable cost. Readily accessible facilities.
Provide educational leisure time activities. Base activities on interests of citizens.

Maximize present investment.

Protect and minimize present investment.

Use measures other than purchase when possible, such as dedication, zoning. 
6. Encourage multipio use of properties.

7. Vtilize land use patterns which enhance open space and recreation.
Provide fir passive recreation on conservation and other Town lands.

Provide for PUD and cluster zoning.
Maximize use of present and future areas and facilities.

Use innovative land use controls.

\section{GOALS RELATED TO RECREATION AND/OR OPEN SPACE 1987}

\section{GOALS}

1. Create linkages.

2. Enhance urban design.

3. Balanced neighborhood facilities.

4. Minimize impact on tax rate.
OBJECTIVES

Development a plan of linkages.

Establish design guidelines.

Serve all neighborhoods with a full range of municipal facilities.

Design facilities to minimize maintenance.
5. Continue high quality service delivery of open space and recreation opportunities.
Create long-range maintenance plan for all open space and recreation sites.

\section{POLICIES}

Use methods other than purchase when appropriate. Establish multiple purpose linkages when appropriate.

Us: methods other than purchase wi' ? appropriate.

Mut tiple use of areas and facilities where appropriate.

Utilize appropriate federal and state programs. schedule expenditures so that they are not impacting the rate.

Reduce maintenance cost. Assure that all facilities receive equal maintenance. 
In order to determine the condition of playing surfaces and equipment, amenities offered at the site, both natural and man-made and to identify land uses adjacent to the site, Town owned open space areas and recreational facilities were inspected on several occasions. Additional factors such as provision for handicapped access, lighting, signage and fencing were also included in the inspection process. Photographs of all sites were taken to assist in identifying underutilized areas or potential assets and are on file.

Hudson contains more than thirty publicly held open space and recreation sites that have traditionally offered Town residents a wide variety of leisure options. The sites range from playgrounds and parks that are the location of recreational programing activities sponsored by the Division of Recreation, to well sites and a Town Forest maintained by the Department of Public Works. The Conservation Commission supervises many wetland and open space areas Townwide, and the school Department also offer recreational opportunities. Moreover, other public and private organizations own property in Hudson that is used for leisure or conservation purposes. Many of these sites including, a riverfront park, several ballfields and conservation areas have been donated to the Town by residents.

Reliance on local goundwater as the primary source of potable water has prompted the community to institute aquifer protection programs. The purchase of several properties adjacent to existing well fields has resulted in the preservation of a significant amount open space. Most recently, the Town acquired nineteen acres of land, off Brook Street, from the Sauta Realty Trust for $\$ 600,000$ to be used for aquifer protection, open space or other municipal purposes, bringing the total of publicly owned open space and recreational land to 621.10 acres.

The Hudson Division of Recreation and the Department of Public Works have adopted a close working relationship to share responsibility for the sites. Groundskeeping and maintenance of the sites are carried out by the Department of Public Works while the Division of Recreation conducts programing activity and coordinates events. The Department of Public Works also maintains those portions of public school sites used by the Division of Recreation.

Although the responsibility for planning, providing, and maintaining open space and recreation areas is divided among various departments and commissions the ultimate authority rests with the Town Meeting. The Planning Board is required by Massachusetts General Law Chapter 41, Section 81-D to create a Master Plan to include, among other items, parks, parkways and playgrounds. The General Law also includes provision for the revision of an existing plan or the making of a new plan. The conservation commission also assumes responsibility for the preparation of a plan. Massachusetts General Law Chapter 40, Section $8 \mathrm{c}$ calls for the preparation of plans that may include a conservation and passive outdoor recreation plan consistent with the Town Master Plan. 


\section{INVENIORY}

The following pages contain a site by site review of publicly held, or privately held but used by the public, open space and recreation areas in Hudson. Sites are listed alphabetically, with an inventory of Town owned property preceding property owned by other governmental entities, and privately owned but used by the public open space and recreation areas listed last. A summary of sites inventoried identifying the site, its ownership and size may be found at the end of the section.

The Town of Hudson contains more than thirty Town owned as well as and several other fine open space and recreation facilities held by other entities. The following inventory of these passive and active recreational areas is a summary of location; ownership: the agency responsible for management of the site; zoning; acreage; use; condition; and recreation equipment, where appropriate.

\section{TOWN OWNED OPEN SPACE AND RECREATION SITES}

\section{APSLEY PARK}

Location: Riverview and Port Streets

Ownership: Town of Hudson

Agency: Park Commission/Department of Public Works

Zoning: SB

Area: 87,120 square feet 2 acres

Use: Passive

Condition: Fair

Equipment: None

\section{CENIENNIAL BEACH}

Location: Fort Meadow Reservoir

Ownership: Town of Hudson

Agency: Park Commission/Department of Public Works/Conservation Commission

zoning: SB

Area: 348,480 square feet 8 acres

Use: Active

Condition: Fair

Equipment: Dock system Row boat with oars

comfort station Playground equipment

\section{CHAPIN FIELD}

Location: Chapin Road

Ownership: Town of Hudson

Agency: Park Comnission/Department of Public Works

Zoning: $\mathrm{SB}-1, \mathrm{SB}-3$

Area: 193,842 square feet $\quad 4.45$ acres

Use: Active

Condition: Good

Equipment: 2 Baseball diamonds

Dugouts

Concession stand

2 Backstops

Benches

scoreboard 
TOWN OWNED OPEN SPACE AND RECREATION SITES - CONTINUED

CHERRY STREET PLAYGROUND

Location: Cherry Street

Ownership: Town of Hudson

Agency: Park Commission/Department of Public Works

Zoning: $\mathrm{M}-4$

Area: 179,903 square feet $\quad 4.13$ acres

Use: Active

Condition: Good

Equipment: Softball diamond Playground equipment

Fenced

CRYSTAL SPRINGS

Location: Still Drive

ownership: Town of Hudson

Agency: Conservation Commission

Zoning: SB

Area: 205,168 square feet $\quad 4.71$ acres (Portion of site in Hudson)

Use: Passive

Condition: Good

Equipment: None

DANFORTH CONSERVATION AREA (Including Pickles Pond)

Location: Lincoln street

omership: Town of Hudson

Agency: Conservation Commission

zoning: $S A-8$

Area: $2,256,408$ square feet $\quad 51.8$ acres

Use: Passive

Condition: Good

Equipment: None

FARINA FIELD

Location: Cox and Manning Streets

Ownership: Town of Hudson

Agency: Park Commission/Department of Public Works Zoning: SA-8

Area: 114,563 square feet 2.63 acres

Use: Active

Condition: Good

Equipment: Baseball diamond 
GATES POND/CRYSTAL SPRING

Location: Town of Berlin

Ownership: Town of Hudson

Agency: Department of Public Works

Zoning:

Area: $3,484,800$ square feet 80 acres (Portion of site in Berlin)

Use: Passive

Condition: Good

Equipment: None

HOG BROOK

Location: Off Route 62, near Linden Street

Ownership: Town of Hudson

Agency: Conservation Commission

Zoning: $S B-3$

Area: 503,554 square feet 11.57 acres

Use: Passive

Condition: Good

Equipment: None

LAND, OFF CAUSEWAY STREET

Location: Off Causeway Street

Ownership: Town of Hudson

Agency: Conservation Commission

Zoning: $S A-8$

Area: 22,215 square feet .51 acres

Use: Passive

Condition: Good

Equipment: None

\section{LIBERTY PARK}

Location: Wood Square

Ownership: Town of Hudson

Agency: Department of Public Works/Park Commission

Zoning: $\mathrm{C}-1$

Area: 11,861 square feet $\quad .27$ acres

Use: Passive

Condition: Good

Equipment: Benches 
MORSE PROPERTY

Location: off Causeway street

Ownership: Town of Hudson

Agency: Conservation Commission

Zoning: SB

Area: 696,960 square feet 16 acres

Use: Passive

Condition: Good

Equipment: None

MOULTON'S FIELD

Location: Dewey, Marion and Felton streets

Ownership: Town of Hudson

Agency: Department of Public Works/Parks Commission Zoning : $\mathrm{SB}$

Area: 152,460 square feet 3.5 acres

Use: Active

Condition: Good

Equipment: Basketball court Tennis court

Softball diamond Playground equipment

Fenced

Lighted

O'DONNELL FIELD

Location: Brigham Street

Ownership: Town of Hudson

Agency: Department of Public Works/Parks Commission

Zoning: SB

Area: 462,607 square feet 10.62 acres

Use: Active

Condition: Good

Equipment: Baseball diamond Backstop

4 soccer goals

PIERCE ESTATES

Location: Off Murphy Road

Ownership: Town of Hudson

Agency: Conservation Commission

Zoning: SA-5

Area: 174,240 square feet $\quad 4.00$ acres

Use: Passive

Condition: Good

Equipment: None 
PUMPING STATION

Location: Cox Street and Municipal Drive

Ownership: Town of Hudson

Agency: Department of Public Works/Parks Commission

zoning: $M-1, M-5, M-7$

Area: 143,748 square feet 3.3 acres

Use: Active (no longer used)

Condition: Poor

Equipment: 2 Ice skating areas Lights

\section{RIVERSIDE PARK}

Location: Chapin and Brigham Streets

Ownership: Town of Hudson

Agency: Department of Public Works/Parks Comnission

Zoning: SB

Area: $1,102,068$ square feet 25.3 acres

Use: Active

Condition: Good

Equipment: Football field

Bleachers

Track

concession stand

Lights

Ticketbooth

Restrooms

Fence

Baseball diamond

Dugouts

Tennis courts

Clubhouse

Backstop

Bubbler

Playground equipment

SAUTA PROPERTY

Location: off Brook Street

Ownership: Town of Hudson

Agency: Conservation Commission/Department of Public Works/Parks Commission zoning: SA-8

Area: 827,640 square feet 19 acres

Use: Passive

Condition: Good

Equipment: None

TOWN FOREST

Location: River Road

Ownership: Town of Hudson

Agency: Department of Public Works

Zoning: SB

Area: 936,540 square feet $\quad 21.5$ acres

Use: Passive

Condition: Good

Equipment: None 
TOWN OWNED OPEN SPACE AND RECREATION SITES - CONTINUED

TRIPPS POND

Location: Green and River Streets

Ownership: Town of Hudson

Agency: Department of Public Works/Parks Commission

Zoning: SB

Area: 326,700 square feet $\quad 7.5$ acres

Use: Passive

Condition: Good/fair

Equipment: None

WOOD PARK

Location: Park Street

Ownership: Town of Hudson

Agency: Department of Public Works/Parks Commission

Zoning: SB

Area: 217,800 square feet 5 acres

Use: Passive/active

Condition: Good

Equipment: Bandstand Shelter

Benches Playground equipment

TOWN OWNED SCHOOLS

COX S'TREET SCHOOL

Location: Cox Street

Ownership: Town of Hudson

Agency: School Department

Zoning: $M-5$

Area: $1,489,623$ square feet 34.2 acres

Use: Active

Condition: Good

Equipment: 2 Softball diamonds Playground equipment Backstops

CARMELA A. FARLEY SCHOOL

Location: Packard Street

Ownership: Town of Hudson

Agency: School Department

Zoning: $\mathrm{SA}-8$

Area: 781,031 square feet 17.93 acres

Use: Active

Condition: Good

Equipment: Baseball diamond Playground equipment

Basketball court 
TOWN OWNED SCHOOLS - CONTINUED

FOREST AVENUE SCHOOL

Location: Forest Avenue

Ownership: Town of Hudson

Agency: School Department

Zoning: $\mathrm{SB}$

Area: 892,980 square feet 20.5 acres

Use: Active

Condition: Good

Equipment: Baseball diamond

Softball diamond

2 Tennis courts $\quad 1 / 2$ court basketball court

Fenced

playground equipment

JOHN F. KENNEDY SCHOOL

Location: Manning street

Ownership: Town of Hudson

Agency: School Department

Zoning: $S A-8$

Area: 930,006 square feet 21.35 acres

Use: Active

Condition: Good

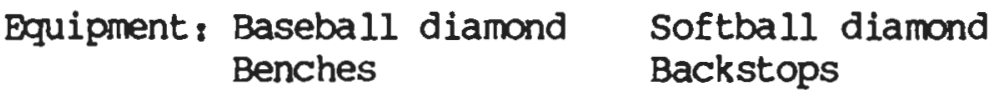

HUDSON HIGH SCHOOL

Location: Brigham street

Ownership: Town of Hudson

Agency: School Department

Zoning: SB

Area: 603,306 square feet 13.85 acres

Use: Active

Condition: Good

Equipment: Gymnasium

HUBERT SCHOOL/KELLY PLAYGROUND

Location: Broad Street

Ownership: Town of Hudson

Agency: School Department/Parks Commission

Zoning: $S A-8$

Area: 58,800 square feet $\quad 1.35$ acres

Use: Active

Condition: Good

Equipment: Playground equipment 
TOWN OWNED WELLS, WELC FIELDS, WATER TANKS AND WATER TOWERS

OOOLIDGE STREET WATER TANK

Location: coolidge Street

Ownership: Town of Hudson

Agency: Conservation Commission/Department of Public Works zoning: $\mathrm{M}-1$

Area: $1,151,726$ square feet $\quad 26.44$ acres

COX STREET WELL

Location: cox street

Ownership: Town of Hudson

Agency: Department of Public Works

zoning: SB

Area: 443,440 square feet $\quad 10.18$ acres

CRANBERRY WELL

Location: Parmenter Road

Ownership: Town of Hudson

Agency: Department of Public Works

Zoning: $S A-8$

Area: $1,160,438$ square feet 24.64 acres

NEW WELL \$3

Location: Chestnut Street, north of MBTA railroad tracks

Ownership: Town of Hudson

Agency: Department of Public Works

Zoning: $M-6$

Area: $3,884,245$ square feet 89.17 acres

KANE WELL 1 and DEC WELL \#2

Location: Chestnut Street and Main Street, south of MBTA railroad tracks Ownership: Town of Hudson

Agency: Department of Public Works

zoning: $S A-5$

Area: $2,315,702$ square feet 53.16 acres 
MURPHY WATER TANK

Location: Murphy Road

Ownership: Town of Hudson

Agency: Department of Public Works

Zoning: SA-5

Area: 99,316 square feet $\quad 2.28$ acres

POPE'S HILC WATER TOWER

Location: Belleview Street

Ownership: Town of Hudson

Agency: Department of Public Works .

Zoning: SB

Area: 83,635 square feet $\quad 1.92$ acres

ROUNDTOP WATER TANK

Location: Saratoga Drive

Ownership: Town of Hudson

Agency: Conservation Commission/Department of Public Works

Zoning: $S A-8$

Area: 355,014 square feet $\quad 8.15$ acres

RIMKUS WELL

Location: River Road

Ownership: Town of Hudson

Agency: Department of Public Works

Zoning: $\mathrm{SB}$

Area: 443,876 square feet $\quad 10.19$ acres

OPEN SPACE AND RECREATION SITES OWNED BY OTHER GOVERNMENTAL ENTITIES

STATE FOREST

Location: Main Street

Ownership: Commonwealth of Massachusetts

Agency: Department of Forests and Parks

Zoning: SA-8

Area: 4,782,452 square feet 109.79 acres

Use: Passive

Condition: Good

Equipment: None 
WHITEPOND ROAD WATERSHED

Location: Whitepond Road

Ownership: Town of Maynard

Agency: Town of Maynard

Zoning: $S A-8$

Area: 5,793,480 square feet 133 acres

Use: Passive

Condition: Good

Equipment: None

QUASI-PUBLIC AND PRIVATE OPEN SPACE · AND RECREATION SITES

HUDSON BOYS CLUB

Location: Church Street

Ownership: Non-profit

Zoning: $\mathrm{C}-1$

Area: 25,051 square feet $\quad .58$ acres

Use: Active

Condition: Good

Equipment:

HUDSON GIRLS CLUB

Location: Lincoln street

Ownership: Nonprofit

Zoning: SB

Area: 28,070 square feet $\quad .64$ acres

Use: Active

Condition: Good

Equipment:

NEW ENGLAND FOREST

Location: Chestnut and Murphy Streets

Owership: New England Forestry Foundation

Agency: New England Forestry Foundation

Zoning: SA-5

Area: $1,315,512$ square feet $\quad 30.2$ acres

Use: Passive

Condition: Good

Equipment: None 
SAINT MICHAEL'S BALLFIELD

Location: cox Street

Ownership: Archdiocese of Boston

Zoning: SB

Area: 217,800 square feet 5 acres

Use: Active

Condition: Good

Equipment: Baseball diamond Backstop

Benches

In addition to the sites and facilities listed previously, Hudson contains numerous social and fraternal organizations that offer a wealth of passive, active and cultural activities to Town residents. A complete listing of these groups, clubs and organizations may be found in the Hudson community Guide published by the Hudson Public Library. A summary of existing open space and recreation sites is included on.the next two pages.

SUMMARY OF OPEN SPACE AND RECREATION SITES IN HUDSON

NAME

AREA IN

TOWN OF HUDSON

ACRES

Conservation Areas

Crystal Springs

Danforth Lot

Gates Pond

Hog Brook

Land, off Causeway street

Morse Property

Pierce Estates

Town Forest

Total

4.71

51.80

80.00

11.57

.51

16.00

4.00

21.50

TOWN OF HUDSON

Parks and Recreation Areas

Apsley Park

Centennial Beach

2.00

Chapin Fields

8.00

Cherry Street Playground

4.45

Farina Field Playground

4.13

Liberty Park

2.63

Moulton's Field

O'Donnell Field

3.50

Pumping Station

10.62

Sauta Property

3.30

Riverside Park

19.00

Tripps Pond

25.30

Wood Park

Total

7.50

5.00

95.70 
SUMMARY OF OPEN SPACE AND RECREATION SI'TLS IN HUDSON - CONTINUED

Public schools

Cox Street Schnol $\quad 34.20$

Carmela A. Farley School 17.93

Forest Avenue School 20.50

Fohn F. Kennedy School 21.35

Hudson High School $\quad 13.85$

Total

Hurbert School/Kelly Playground $\quad 1.35$

Wells, Weil Fields, Water Tanks and Water Towers

Coolidge Street Water Tank $\quad 26.44$

$\begin{array}{ll}\text { Cox Street Well } & 10.18\end{array}$

$\begin{array}{ll}\text { Cranberry Well } & 24.64\end{array}$

New well \#3 $\quad 89.17$

Kane Well \#1 and DEC Well \#2 53.16

Murphy Water Tank $\quad 2.28$

Pope's Hill Water Tower $\quad 1.92$

$\begin{array}{lr}\text { Rimkus Weil } & 10.19\end{array}$

Total

Round Top Water Tank $\frac{8.15}{266.13}$

OTHER GOYERNMENTAL ENTITIES

$\begin{array}{ll}\text { State Forest } & 109.79\end{array}$

Total

Writepond Road Watershed-Maynard $\frac{133.00}{242.73}$

QUASI-PUBI, IC AND PRIVATE

Huason Bo:: Club $\quad .58$

Hudson Girls Club $\quad .64$

New England Forest $\quad 30.20$

Total

Saint Michael's Ballfield $\frac{5.00}{36.42}$

In general, Hudson's open space areus and recreation sites are well maint?ined, handicapped accessible and in good condition. Equipment, where provided, is for the most part in a good state of repair. Moreover, many sites are fenced or otherwise insulated from vehicular intrusion and adjacent land uses offer no apparesi hazards to facility users.

Unfortunately, recreation sites are concentrated in the west-central portion of the Town, leaving the eastern portion of the community with little recreational upportunity within walking distance of most residents. However, the acquisition $c$ i a nineteen acre parcel of land formerly owned by the sutra Trust creates the option of developing a recreational facility to service this area. 
The preceding section described the location and type of open space and recreation opportunities $2^{\prime} \cdot{ }^{\prime}$ iable Town-wide. The subsequent section applies accepied recreational planning standards to the Town's existing inventory to determine type, extent and location of additional need. Consideration is also given to open space standards and future need.

Recreational need in a community is usually defined as the unmet demand portion of a supply and demand equation. The cormunity's existing open spacr. and recreation facilities and programs may be termed the supply, while demand may be identified as the Town's population. Recreational programs and participation levels are included in the Appendix. Application of accepted recreational planning standards as identified by various professional organizations, the National Recreation and Park Association park and open space st.andards, are generally acknowledged by planners as being appropriate for use in most communities. Table $\mathrm{V}$ on page 28 , lists relevant recreation standards. Recreational service capacity may be a ratio of the community's population to existing open space and recreation land area, population to special facilities or level of program participation.

current and projected open space and recreational need are examined at both the Town-wide and precinct level. Voting precincts were chosen as unit of comparison due to a lack of current demographic data at the neighborhood level. Table IV, below, summarizes population standards for four broad recreation categor ies.

TABLE IV

RECREATION STANDARDS-SUMMARY

FACILITY

PLAYLOT

PLAYGROUND

PLAYFIELD

PARK
ACRES PER 1,000

RES IDFRTS

$\begin{array}{cc} & \text { varies } \\ & 1.5 \\ & 1.5 \\ \text { TOTAL } \quad \frac{7.5}{10.5}\end{array}$

Source: Universal Engineer $n$ ng Corporation

Each type of recreational area referred to in the previous Table serves a specific user population and may be assigred a geographic service area. Based on the population standards summarized above, Hudson should have approximately one hundred thirty on? acres of parks, twenty-six acres of playgrounds and twenty-six of land devoted to playfields. However, the amount of open space and recreation recommended for a comrunity will vary according to what measure of need is employed. Before revicwing other means of measuring recreational need, a brief description and short explination of each type of facility is contained in the following paragraphs. 
Playlots are most often designed to serve the small children of families located in the neighborhood. The playlot should offer space for running or gairi-piaying, swings, slides and aiso provict objects to climb un or over. protected from veh ${ }^{2}$ cular intrusion, plajiots range from 1,500 to 2,500 square feet to as large as an acre in area and ace usually within a short distance of the users dwelling. Playlots may not be needed in low density areas.

A playground serves a population ranging in age from six to fourteen years. often associated with the neighborhood school, a playground should provide enough room for field games such as softball or soccer. Covering one to five acres, the site shouid also be large enough to allow for tennis, basketball, or handball courta and contain an area for passive games and crafts.

A playfieid generally serves approximately four or five neighborhooäs and should be designed for use by. young people and adults. The site should comprise five to twenty acres of land area devoted to both active and passive recreation. A playfield should provide activities similar to those found in the neighborhood playground. However, additional space for a regulation football or basebali field is often included in the design. Playfields are often lighted, to extend users hours, and may include a swimming pool or other special facility.

Municipal parks afford community residents the opportunity to engage in passive leisure pursuits in a natural setting. In retaining a portion of the community's natural environment, parks provide an respite from the built landscape. Walking, band concerts, nature trails and scenic views are some of the activities that may often be found in local parks. Parks may range in area from vest-pocket size parks of less than one acre, to regional parks that may comprise more than 1,000 acres.

In addition to population standards, several other techniques are sometimes also used to measure of the adequacy of recreation opportunity in a community. The first method involves assigning a service area to each recreational facility identifving those portions of the community served by that particular facility. The second technique assigns a recommended land area devoted to parks and recreation based upon either, a set percentage of the community's land area, or a fixed percent of the recreational land area. All of these methods will be examined in greater detail later in this section.

The Table $V$, on the following page, incorporates several recreation need techniques for six types of open rpace and recreation areas. The standards in Table $V$ have been generated by the National Recreation and Parks Association and have been widely accepted and frequently used. Column one identifies the classification into which six broad categories of open space and recreation sites may be placed. The second column contains a recommended land area standard, in acres per thousand persons, for each category. column three provides a range of recommended facility sizes. The number of users a site can accommodate, based upon a designated number of square feet allowed per user, may be found in the fourth column. The service area for each category is included in the last column. 
TARTE V

NATICNAL RECREATION AND PARKS ASSOCIA:ION STANDARDS

\begin{tabular}{|c|c|c|c|c|}
\hline Classification & $\begin{array}{c}\text { Acres/ } \\
1000 \text { people }\end{array}$ & $\begin{array}{l}\text { Size } \\
\text { Range }\end{array}$ & $\begin{array}{l}\text { Population } \\
\text { Served }\end{array}$ & $\begin{array}{l}\text { Service } \\
\text { Area }\end{array}$ \\
\hline Playlots & na * & $\begin{array}{l}2,500 \text { sq.ft.* } \\
\text { to } 1 \text { acre }\end{array}$ & $500-2,500$ & Sul-neighborhood \\
\hline $\begin{array}{l}\text { Vest pocket } \\
\text { parks }\end{array}$ & na & $\begin{array}{l}2,500 \text { sq.ft. } \\
\text { to } 1 \text { acre }\end{array}$ & $500-2,500$ & Sub-neighborhood \\
\hline $\begin{array}{l}\text { Neighborhood } \\
\text { park }\end{array}$ & 2.5 & $\begin{array}{l}\text { Minimum } 5 \\
\text { acres up to } \\
20 \text { acres }\end{array}$ & $\begin{array}{l}2,000 \text { to } \\
10,000\end{array}$ & $1 / 4-1 / 2$ mile \\
\hline District park & 2.5 & $20-100$ acres & $\begin{array}{l}10,000 \text { to } \\
50,000\end{array}$ & $1 / 2-3$ miles \\
\hline $\begin{array}{l}\text { Large urban } \\
\text { park }\end{array}$ & 5.0 & $100+$ acres & $\begin{array}{l}1 \text { per } \\
50,000\end{array}$ & $\begin{array}{l}\text { Within } 1 / 2 \text { hour } \\
\text { driving time }\end{array}$ \\
\hline Regional parks & 20.0 & $250+$ acres & $\begin{array}{l}\text { Serves entire } \\
\text { populution in } \\
\text { smaller } \\
\text { communities }\end{array}$ & $\begin{array}{l}\text { Within one hour } \\
\text { driving time }\end{array}$ \\
\hline
\end{tabular}

* na $=$ Not applicable

* Sq.ft. = square feet

Source: National Recreution and Park Associatiun

Standards governing the amwunt of undeveloped open community vary a great deal. Sources have placed the amount of undeveloped open space needed by a community at different levels. Suggestions range from ten percent of the community's total area, excluding swamps and water bodies, to ten percent of the total of recreational land in the community, or ten acres of land per thousand persons. Obviously, the open space needs of each community are unique. A town that is heavily dependent upon local groundwater as a source of drinking water may need to acquire larger tracts of land, to preserve and protect local aquifers and aquifer recharge areas, than would a community that imports its water supply. Likewise, the presence or absence of unique natural features, rare or encangered plant or wildlife and the desire to preserve and maintain the rural character of the community are factors to be weighed in each cummunity.

Open space areas and recreation sites must be examined together in order to develop a comprehensive view of community assets and needs. The integration of open space and recreation needs to establish a Town-wide assessment follows a needs assessment for each category. 
Recreational need

Huäsor's existinn recreational land area is comprised $\mathrm{C}^{\circ}$ approximately twenty sites totaling, se than 200 acres, or 11.7 acres of recreation land per trumand residents. When matched against national standards it can be seen that Hudson falls short of the recommended standards in most categories, and exceeds recommended land area in two categories. Table VI compares projected recreational need, based on istional recreation standards, to existing recreational opportunity.

TABLE Vis

HUDSON RECREATIONḦL NEED

(land area)

\begin{tabular}{|c|c|c|c|}
\hline Classification & $\begin{array}{l}\text { Existing } \\
\text { land area } \\
\text { (in acres) }\end{array}$ & $\begin{array}{l}\text { Recommended } \\
\text { land area } \\
\text { (in acres) }\end{array}$ & $\begin{array}{l}\text { Difr arence } \\
\text { (in acres) }\end{array}$ \\
\hline Playlots & 19.28 & 17.00 & $\therefore 28$ \\
\hline Vest Pocket Parks & 11.70 & 17.00 & 5.30 \\
\hline Neighbornood Parks & 162.45 & 43.75 & +118.70 \\
\hline District Parks & 25.30 & 43.75 & -18.45 \\
\hline Regional Parks & -- & 250.00 & $-250.00 *$ \\
\hline rotal & $\overline{204.88}$ & $\overline{391.00}$ & $=152.77$ \\
\hline
\end{tabular}

* When acreage required for a regional park is omitted, planning standards for recreation area in a coli.iunity is exceeded by nine! $i$-seven acres.

Source: Na: i Recreation and Park Association

Assessor's records, Town of Hudson

As can be seen in the Table above, recreation land devoted to neighborhood parks, e.g. parks five acres or larger, far exceeds the recommended land area for a community with a population $O_{i}$ 17,500. In most other categories the Town is well below the standard recommended by the National Recreation and Park Association for land area devoted to parks. However, accepted planning stardards call for a regiona \& park within a one hour drive of the cmmunity. Whil Hudson does not have a regional park, there are severai regional recreation arcas within a one hour drive of the Town, Ashland State Park, Hopkinton State Park and Great Meadows National Wildlife Refuge. Comparison of existing recreational land to standards for 'iree broad recreation categor $i$.is 
identifind in Table IV demonstrates that Huason exceeds the land area recommendation for playlots, playgrounds and playfields. Both of these totals are somewhat misieading. Acreage figures for recreation facilities located on public school grounās include the land area of the entire site, while only a relatively small portion of the site may actually be used for recreation. Aiso, the total of existing Town-wide acreage devoted to recreation compared to national planning stariuicis does not address areas in the community that may be lacking access to recreation opportunity at the neighborhood level.

Fquitable distribution of recreational opportunity is as important a measure of neea as is total land area devoted to recreation, especially ir. commurities lacking public transportation. Distribution of facilities may be examined from three perspectives. Perhaps the primary consideration is the proximity of facilities to local population concentrations. For the purposes of this report population to recreation opportunity ratios and comparisons will be examined Town-wide and at "he precinct level. See Table VII. Next, the size of the facility will determine the extent of the service area. Hence, those portions of the community not included in a service area may be considered to be in need of additional recreation facilities. Following loc tion and size, the type of event or recreational programing available at the site may be such as to extend the service area of the facility to the entire community, e.g. the adult aerobics program held in tive Hudson High Schooi gymnasium and sponsored by the Recreation Division attracts participants Town-wide.

TABLE VII

HUDSON POPULATION BY PRECINCT 1985

PRECINCT

\begin{tabular}{ll}
1 & 2,336 \\
2 & 2,407 \\
3 & 2,337 \\
4 & 2,548 \\
5 & 2,473 \\
6 & 2,570 \\
7 & 2,580 \\
\hline
\end{tabular}

Total 17,251

Source: Office of Secretary of the commonwea ith

Precinct populations, as would ie expected, are very similar. However, the precincts vary a great deal in density, size avd recreation space. Table VIII compares population to recreation land area for each precinct. 
TABLE VIII

POPULATION AND RECREATION I,AND AREA BY PRECIINT

POPULATION

RECREATION

ACRES PER

HUDSON

LAND AREA

1,000 PERSONS

$$
17,523 * \quad 204.88 \quad 11.70
$$

PRECINCT

$\begin{array}{rrrr}1 & 2,336 & 68.72 & 29.87 \\ 2 & 2,407 & 17.93 & 7.47 \\ 3 & 2,337 & 64.98 & 28.25 \\ 4 & 2,548 & 19.00 \star \star \star & 7.60 \\ 5 & 2,473 & 28.50 & 11.88 \\ 6 & 2,570 & 1.62 & .65 \\ 7 & 2,580 & 7.63 & 3.05 \\ \text { IOTAL } & 17,251 * * & \frac{7.38}{208.38} \star \star \star & \end{array}$

* 1986 population

** 1985 population

*** Sauta property has been recently acquired and is undeveloped.

$\star \star \star \star$ Differences due to rounding.

Source: Nationil Recreation and Parks Association

ofice of Secretary, Commonwealth of iassachisetts

Assessor's Office, Town of Hudson

Three of Hudson's precincts exceed the Town-wide ratio of eieven and seven tenths acres of recreational land per 1,000 residents, the remaining four fall below the Town-wide ratio. of the three, only precinct Five approximates the Town-wide average, Precincts one and Three contain a disproportionately large amount of recreation land relative to other precincts in the comunity. Precincts Two and Four appear to contain an amount of recreational land just short of the 'Town-wide ratio but a closer examination reveals that each precinct has but one area, the Farley jchool in Precinct Two and the undeveloped Sauta Property in Precinct Four. Precincts Six and Seven, with less than tin fcres and less than eight acres respec:-vely, fall well below the Town ratio. A map of Hudson's seven precincts may be fouisu on we following page. 
(1)

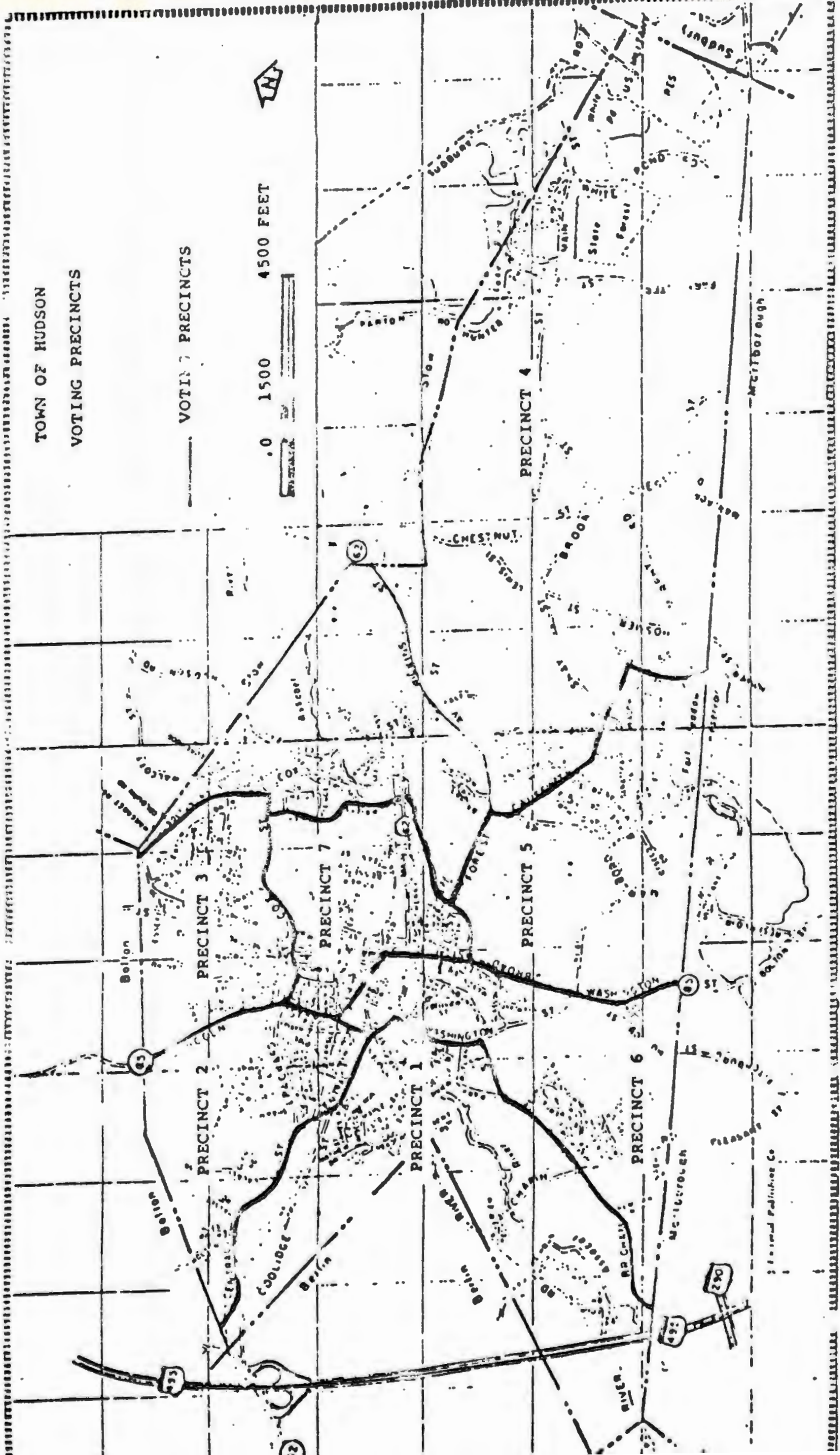


ine summary standards on page 24 recciimend ten and one half acres of recreation land per 1,000 persons and recommended recreation and open space standaràs on page 26, twenty-two and three tenths acres per 1,000 persons, wore used to identify current recreational need at the precinct level. Table IX, bejow, lists existing recreation land area and accepted planning standards, by precinct.

TABLE IX

EXISTING RECREATION LAND AREA

$\begin{array}{rccr}\text { PRECINCT } & \begin{array}{c}\text { EXISTING RECREATION } \\ \text { LAND AREA }\end{array} & \begin{array}{c}\text { SUMMARY } \\ \text { STANDARDS }\end{array} & \begin{array}{r}\text { NATIONAL RECRE } \\ \text { AND PARKS ASSO }\end{array} \\ 1 & 68.72 & 24.15 & 51.38 \\ 2 & 7.47 & 25.20 & 53.61 \\ 3 & 64.98 & 24.15 & 51.38 \\ 4 & 19.00 & 26.25 & 55.85 \\ 5 & 28.50 & 25.20 & 53.61 \\ 6 & 1.52 & 26.25 & 55.85 \\ 7 & 7.63 & 26.25 & 55.85 \\ \text { TOTAİ } & 208.38 & \underline{177.45} & 377.53\end{array}$

Source: Assessor's Office, Town of Hudson

Universal Engineering Corporation ( $T_{i}$, as Planning Associates Division) inutional Recreation and Park Association

As Tabie XI illustrates, the distributior. of facilities throughout the community is uneven. Town-wide Hudson exceeds accepted park standards, with the exception of the land area required for a regional park. However, the inequities created by uneven distribution of recreation opportunity must be ad̃dressed.

A second rethod of assessing a comminity's recreational need is to define the geographic area served by each facility. This is usuaily done by assigning a radius in miles to each facility based upon the size of the facility, e.g. a recreation area of up to five acres has a service area of $1 / 4$ mile radius. The service area of each facility in the comunity may then be mappeu, portions of the community iying outside service areas are determined to be areas of need. Table $x$ contains accepted standards used in defining services areas.

However, there are several circumstances werein a service area, based on the number of square fo... a site contains, fails to fully represent the true geographic are. from whici users are drawn. Consideration must be given to facilities that may be relatively small in size, and lherefore are represented as having a small servicr area, but have a more extensive service area due to lesirable recreational programs that attract residents from outside the service area. The adult aerobics program offered in the Hudson High 
wnowi gymnasium is one such exampie. The site totals approxinately fourteen acres. According to accepted standards the site would service the recreational needs of residents within a $1 / 2$ mile radius, however, the program attracts participants from all parts of Hudson. Special facilities, swiming pools, skating riniks or in Hudson's case, Riverside Park, may also attract participants and spectators Town-wide as weil as from neighboring iowns and thus serve a much larger area.

TABLE X

FUCREATIONAI SERVICE AREAS

\begin{tabular}{|c|c|}
\hline ACREATE & $\begin{array}{l}\text { SFRVICE ARLAA } \\
\text { (radius) }\end{array}$ \\
\hline $\begin{array}{l}2,500 \text { square } \\
\text { feet to } 1 \text { acre }\end{array}$ & Sub-neighborhond \\
\hline 1 to 5 acres & $1 / 4 \mathrm{mile}$ \\
\hline 6 to 20 acres & $1 / 2$ mile \\
\hline 20 to 100 acres & 1 mile \\
\hline $100+$ acres & 3 miles \\
\hline
\end{tabular}

Application of these standards to Hudson's existing recreation facilities, as shown on the following maps, provides a very clear graphic representation of - creation need. The Open Space and Recreacion Areas map on page 35, identifies all Town-crned parks or active recreation sites. The map on page 36 contains the recreationai service areas for all parks and playgrounds. Service areas for Hudson public schools are based upon the acreage of the entire site.

As can be seen in the map of parks and recreation sites, facilities are concentrated in older, more densely populated we-'./central Hudson. In the eastern less densely populated purtion of Town, there are no recreation iacilities east of Centennial Beach. The Town has recently acqui red nineteen acres of rind in eastern Hudson to be ueveloped for recreation purposes. This acquisition offers Hudson the chance to establish a much needed active recreation facility in an area currently without such opportunity.

Perhaps due to the irregular shape of the Town, other locations removed from its center are not well served by existing facilities. The outlying areas aiong the north/central, north/western and south/western borders all lie outside park and active recreation service areas. The residents of these neighborhoods must journey closer to the Town's center to enjoy recreation facilities. 


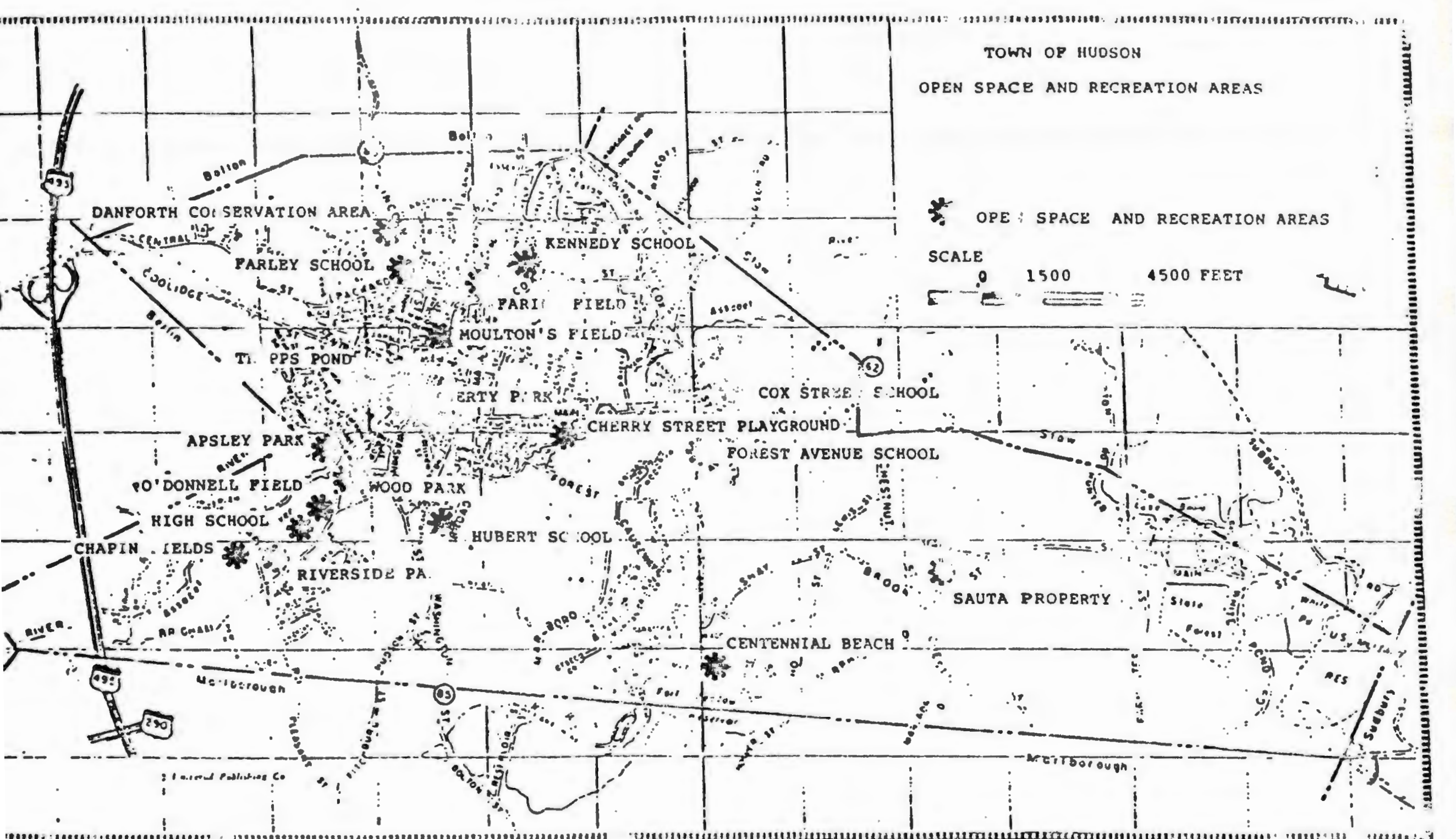




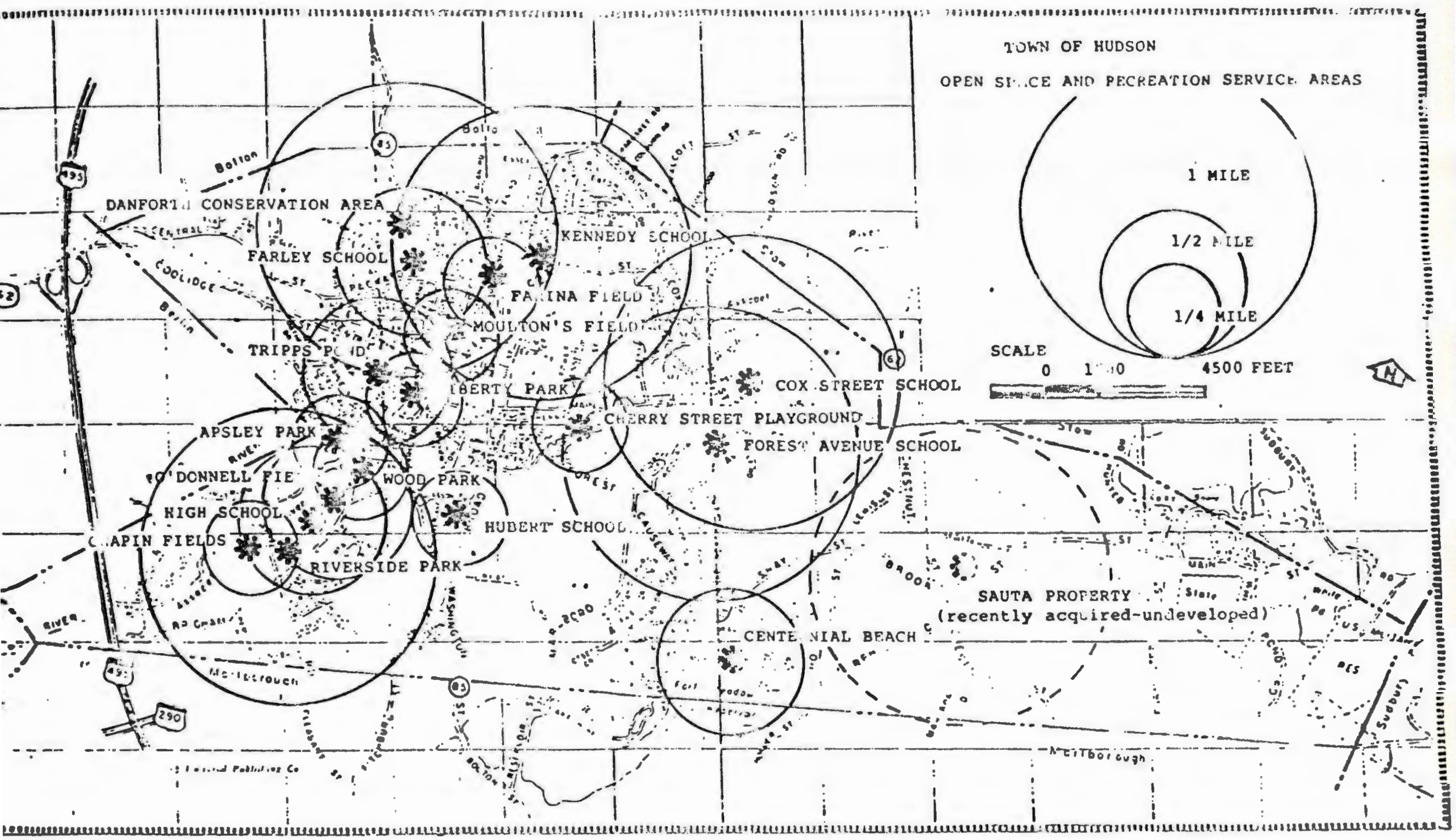


Active recreation facilit: , iocated on the grc:-iads of Hudson pubiic schools make a significarit contribution - the number and distribution of recreation sites rown-wide. Aimost all of the Tu .. s school sites mnitain a variety of activities. Nany sites offer a basebail diamone tennis courts or busretibail courts as weil as open play areas anā playground equipmer:

As can be seen in the seconä map, the recieation service areas of Huäson public schooi:s extend weil into olitiying portions of the Town. Service areas for Hudson's puibic schools were generated by using acreage figures for the entire site, an attempt to create a balance between a smailer service area based on oniy that portion of the site actually used for recreation and the presence of speciai facilities that attract users from a much larger area.

Gen Sizace, 'Nonservation Need

Each conwinity across the Commonwealth has open space needs that are unigue to tr.:- community. in rurāi locations, Towns may be motivated to preserve exturisive areas of open space as a means of protecting natural resources. Q:ality of iife considerations may also piompt a rural community to keep large portir ; of the Town in a naturai state in an attempt to retain the pastoral cr.- eristics that first attracted residents. The need to proteci- the TGini:s natural resources may require tre preservation of prime agricultural lanjis; fijundwater resources or watersheds and rare or enäangered piant an" animai infe.

In cienseiy posuiated areas, proviaing city dweliers with an opooitunity to enjoy passive recreation in an urban enviconment may be the prim $y$ reason .. preserving open space. Per̆aps nuwhere is the reec Eor open mace as a source of passive recreation gr-ter thas in an urban setting. An exterisive built ervironment ard nigh iand vaiues often preciude acquisition and make retention cf. píivately held unöeveioped parcels difficuit. Demanö for active recreation sites and interse development pressures oiten comine with a lack of public funäs with which to purchä ${ }^{2}$ available sites, which severely limits irban $C_{n}$. A space. In the face of such constraints demanci for open space may gjo unânswereci.

Aithough not a strictiy rural or farming community, the Town of huäson belongs to ire first group. Due to the Hudson's complete reliance on iocal girouncivater as the ...e source of potable water, every calition wiust be taken to prevent the degrar ion of Town water sourv.j. To this end the Town nas alreacy protected more than two hundred ard twenty acres of land arolina the Town's weil fields and other water sources. The neighiboring Town of Maynard has a. extersive: choiding in Huỏson aimea at protecting water resources. Tre Wiitepond Road Watershed, in northeastern Huäson, comprises 133 acres of linàeveioped land. A. continued high quality of runoff w: "er is a: "ired by sparse deveiopment in the watersined. Huason is also rapidly suburbanizing; thereEore, care must be taken if the mowi is to continue to grow without aitering the quality of locai groundwater and to maintain an adequate future water supply.

Generally, nationally accepted standards governing the amount of open space required by a comurity make little distinction between urban and rural conunzties. Onen space land area recommendations are often bi d on the community's population, not land use characteristics. When this method is 


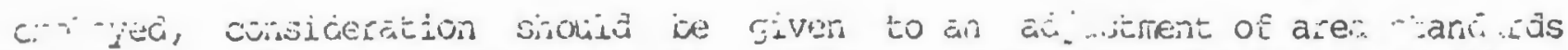

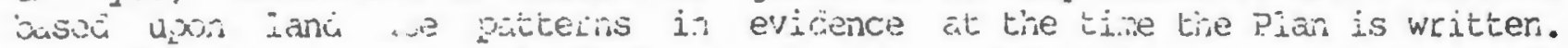

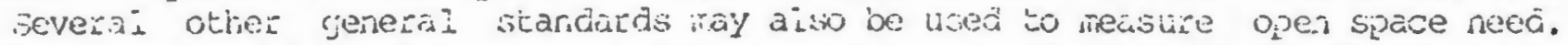

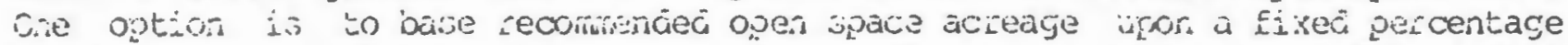

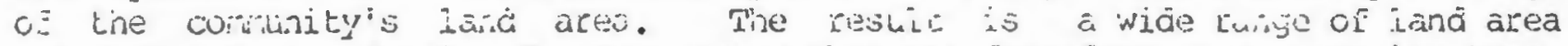

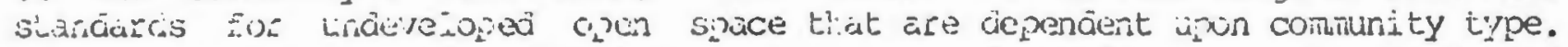

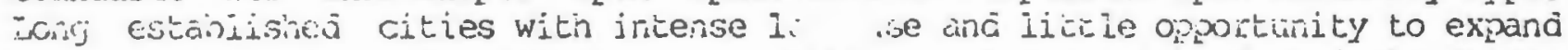

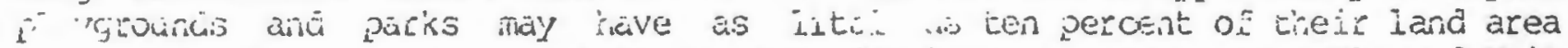

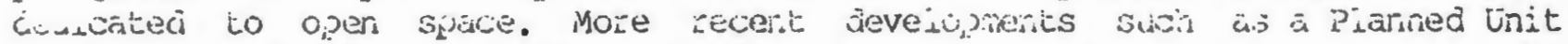

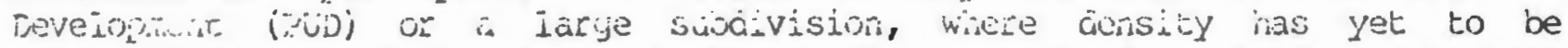

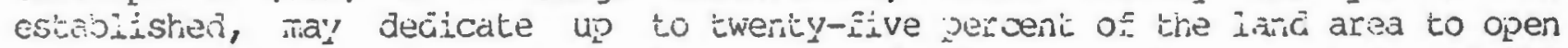
space. "sccono jiumiod is to ceoorinena tiüt a set percentage of tre

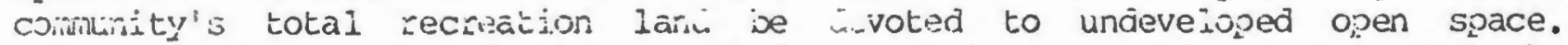
jijorturateiy, boin of these methods contair assuriotions tiat must be icikrvilesigea prior to employirg either methon. Neither rethod includes - ovision Eor hine Fown's land use, gross popuiation, or popuzztion density. Ii. aùdition, in communities which are deficient ir recreation land jrreage, -comnenciariois for open siane based on recreation iand totai woina resur in a iess than adequate amount of open space.

Caicuiation of tiuason's open space iand area neeć based on each of the methods is inciucre in Table Xi.

$\because$ Uñ XI

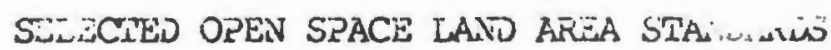

\begin{tabular}{|c|c|c|c|c|}
\hline$S_{\perp} A N D A K D$ & $\begin{array}{l}\text { RECOMMEN UED I... I AREA } \\
\text { (IOTAL IN A:- :-S) } \\
\end{array}$ & 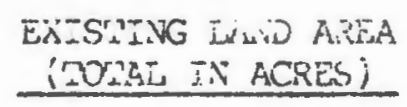 & & $\begin{array}{l}\text { DIRE ARENCE } \\
(\because A C R E) \\
\end{array}$ \\
\hline $\begin{array}{l}\dot{v} \text { inces Pez } \\
\dot{1}, 000 \text { resicients }\end{array}$ & $\$ 75.23$ & $416.22 *$ & + & 240.99 \\
\hline $\begin{array}{l}\text { IG \& oi entice } \\
\text { iar.ä acea }\end{array}$ & 755.84 & 416.22 & - & 339.62 \\
\hline 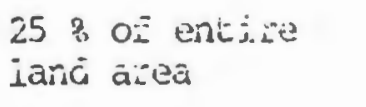 & $1,609.60$ & $4 i 6.22$ & - & $1,473.38$ \\
\hline 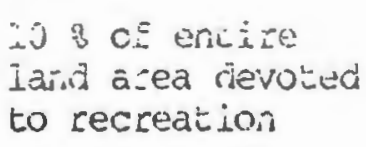 & 20.48 & $204.38 * x$ & + & is4.40 \\
\hline $\begin{array}{l}25 \text { \& of entir: } \\
\text { iand artia rivisea } \\
\text { io recreis. }\end{array}$ & $5 I .22$ & 204.88 & + & $\$ 53.60$ \\
\hline 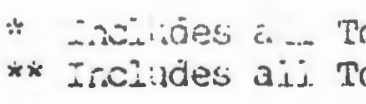 & $\begin{array}{l}\text { owhec: conseivation lo } \\
\text { owreu zecreation iano }\end{array}$ & $\begin{array}{l}\text { a wii siter. } \\
\text { scricoi sites. }\end{array}$ & & \\
\hline
\end{tabular}


The Table demonstrates how wide a range of open space land may be recommended for a community depending upon the standard employed. As can be seen in Table XI, Hudson's existing open space land area exceeds three of the five selected open space standards identified in the Table.

As applied to Hudson, calculation of needed open space based on the first standard, 10 acres per 1,000 residents, approximates the amount of Town-owned conservation land. This figure does not reflect the need to protect groundwater resources, an issue of overiding concern in Hudson.

It appears that open space recommendations based on a fixed percent of total land area overestimates current need, but may be useful in a developing community when estimating maximum population and future need for open space. Hudson would need to acquire 558 more land to meet a standard calling for ten percent of community to be open space, and 4.5 times the acreage of existing open space if the $25 \%$ standard used used to calculate need.

Finally, the last two standards used in Table XI, dedicating a fixed percentage of all recreation land to open space, result in recommendations that fall far short of Hudson's existing open space. In a built community, with limited opportunity to acquire open space, these standards may be helpful in determining allocation of resources or placement of activities. However, its use in Hudson should be limited to the amount of open space contained in a single playground or playfield.

\section{Conclusion}

The Town of Hudson contains more than 200 acres of recreation land located in approximately twenty public sites used by town residents. These facilities are generally in good condition with equipment, where provided, in similar good condition. Most sites are protected from motor vehicle traffic by fences and playground equipment is often setback to the interior of the sites. As in many active communities, Hudson's public recreation facilities are in great demand by citizens and local organizations and subject to intensive use.

Town-wide, the amount of land dedicated to recreational use appears to be adequate for Hudson's current population. However, inequities in the distribution of facilities within the community result in limited recreation opportunity in several sections of Town. Development of the former Sauta property into a recreation area will greatly increase recreational opportunity in the eastern portion of Hudson. Attention should be focused on upgrading facilities at underutilized sites. Creating additional ballfields or establishing walking or jogging paths with exercise stations or biking paths in little used areas may alleviate scheduling and crowding problems at popular facilities.

Hudson also has a considerable amount of Town-owned undeveloped open space, some twenty-three acres per 1,000 residents. As a result of Hudson's dependence on local groundwater resources a majority of Town-owned open space in the Community is dedicated to groundwater or well site protection. A continuing effort should be made by the Town to maintain the integrity of its groundwater supply by protecting environmentally sensitive aquifer recharge areas. Acquisition of sensitive areas, through purchase or gift should continue as vital parcels of land come on the real estate market. 
There are several open space areas, such as the Danforth Conservation Area, Apsley Park and Centennial Beach, where tree shaded trails present the opportunity to view Danforth Falls, walk beside the Assabet River or retreat from a hot beach into the cool shade of a mature forest. A wonderful source of passive recreation, these sites should be preserved and maintained for future generations.

Hudson also contains several other open spaces of considerable acreage. In addition to Town-owned sites, the state Forest, located in the eastern end of Town, comprises over 100 acres of undeveloped land. The New England Forest also owns a large parcel, approximately 30 acres, of undeveloped land.

In summary, the Town of Hudson contains many parks, playgrounds and open spaces that offer a wide variety of leisure activities for residents to enjoy. Equitable distribution of recreational opportunity and upgrading of existing facilities are primary issues along with, protection of groundwater resources and preservation of rural character. The next section lists open space and recreation recommendations based upon identified need and community goals. A Five Year Action Plan that establishes priorities and creates a timetable for the implementation of recommendations assigns follows the recommendations section.

\section{OPEN SPACE AND RECREATION RECOMFIENDATIONS}

An analysis of open space and recreation opportunity in Hudson identified three broad categories of need within the community. Acquisition of additional land in those portions of Town not adequately served by existing facilities. Additional acquisitions would preserve open space and provide a more equitable distribution of recreation areas. The need to establish programs and policies to upgrade existing facilities in order to enhance recreational opportunity and maximize the utility of all Town parks, playgrounds and open spaces. The Town should also formulate a long range maintenance plan to document maintenance costs, ensure that fiscal resources are used efficiently and for evaluating long term costs and benefits. General recommendations relating to acquisition, utility and maintenance follow.

General Recommendations

Acquisitions

- Acquire additional land for recreation purposes in the rapidly developing eastern portion of Town.

- Promote the use of bylaws and/or incentives that encourage developers to donate open space or recreation land, or contribute to funding an open space acquisition program.

- Continue to acquire property adjacent to Town well sites and envi ronmentally sensitive areas.

- Acquire easements along the banks of the Assabet River that will allow pedestrian travel to and from wood Park and $O^{\prime}$ Donnell Field. 
Enhance Opportunity

- Continue the coordinated effort between the Town Planning Board and the Division of Recreation in fostering cooperation with Planning Boards of neighboring communities in establishing a regional bikeway on the unused Massachusetts Bay Transportation Authority right-of-way.

- Continue efforts to establish an Assabet River Park, utilizing all Town owned land adjacent to the River, including the parcel on South Street.

- Modify type of recreational activity where appropriate, to better address the needs of the community.

- Construct a sports complex at Riverside Park.

- Install jogging or walking trails with exercise stations in existing parks.

- Better utilize underdeveloped or underused open space and recreation sites.

- Reuse former railroad right-of-way to include walking, jogging or biking trails.

- Redesign driveway of the Cox street school to allow better recreational use of large front lawn.

Maintenance

- Create, adopt and implement a long range comprehensive maintenance plan for all Town-owned open space and recreation sites.

- Install additional or improve existing lighting at appropriate sites to increase security and extend user hours.

- Reduce or remove undergrowth that hinders scenic views and inhibits policing of parks and open spaces.

- Continue active enforcement of existing park curfew to mitigate litter and vandalism problems.

- Establish a recreation awareness/environmental education program aimed at reducing repair and maintenance costs by educating all residents in the proper care and use of open space and recreation areas. 


\section{Site Recommendations}

The following section includes recommendations for each recreation site inventoried in this Plan. Recommendations proposed were derived from opinions voiced by Town residents during the course of several public meetings, application of a variety of accepted planning standards and observations made during site visits.

\section{- APSLEY PARK}

Action

Clear excess undergrowth from along the banks of the Assabet River to enhance viewlines and security. Repair bridge connecting Apsley and Wood Parks. Increase policing activity to reduce litter and graffiti.

Funding Source

Recreation Division maintenance budget. Department of Public Works maintenance budget. Land and Water Conservation Fund.

- centennial beach

Action

Replace missing playground equipment. Erect barrier to prevent automobiles from entering site after closing hours. Increase policing activity to reduce litter and graffiti. clear excess undergrowth in woods to enhance security.

Funding source

Recreation Division maintenance budget.

Department of Public Works maintenance budget.

Land and Water Conservation Fund.

- CHAPIN FIELD

Action

Regrade and resurface infield areas. Level and turf outfields. Replace fencing and backstops as needed. Improve spectator seating.

Funding source

Recreation Division maintenance budget. Department of Public Works maintenance budget. 
Site Recormendations-Continued

- CHERRY STREET PLAYGROUND

Action

Enhance all recreational opportunities at playground.

Light facility for night use.

Utilize proximity to River to create waterfront walkways.

Construct exercise stations along proposed walkway.

Add a basketball and tennis court.

Funding Source

Recreation Division maintenance budget.

Department of Public Works maintenance budget.

Land and Water Conservation Fund.

- COX STREet ICE SKATING AREA

Action

Recycle unused ice skating area into an active recreation use requiring small area, e.g. tot-lot, basketball or tennis courts.

Funding Source

Recreation Division maintenance budget.

Department of Public Works maintenance budget.

- COX STREET SCHOOL

Action

Realign existing driveway to pass closer to school building to allow recreational use of front lawn.

Funding Source

Recreation Division maintenance budget.

school Department maintenance budget.

- DANFORTH CONSERVATION AREA

Action

Clear overgrown trails and paths.

Use area as an outdoor classroom for recreation awareness and envi ronmental education programs.

conduct walking tours to Danforth Falls.

Funding Source

Self Help Program.

Land and Water Conservation Fund. 
Site Recommendations-Continued

- farina field pLayground

Action

Upgrade softball field

Funding Source

Recreation Division maintenance budget.

Department of Public Works maintenance budget.

- tarley school

Action

Increase amount of playground equipment.

Utilize proximity of Farley School to the Danforth Conservation Area to promote recreation awareness/environmental education program.

Funding Source

Self Help Program

Land and Water Conservation Fund

School Department maintenance budget.

- $\quad$ FOREST AVENUE SCHOOL

Action

Resurface tennis courts.

Upgrade ballfield.

Resurface infield.

Level and turf outfield.

Erect backstop.

Light for night use.

Funding source

Recreation Division maintenance budget.

Department of Public Works maintenance budget.

school Department maintenance budget.

- HUDSON HIGH SCHOOL

Action

Give evening recreational use of school gymnasium first priority when scheduling group activities.

Funding Source

None 
Site Recommendations-Continued

- HUBERT SCHOOL/KELLY PLAYGROUND

Action

Reduce size of parking lot, increase size of play area.

Use a low fence or landscaping to separate the play area from the parking lot.

Replace asphalt surface with of play area with grass or sand.

Funding Source

Recreation Division maintenance budget.

School Department maintenance budget.

- JOHN F. KENNEDY SCHOOL

Action

Upgrade ballfields.

Regrade and resurface infields.

Level and turf outfields.

Install fencing and backstops.

Expand open portion of site to accommodate a regulation soccer or field hockey field.

Install lighting for night use.

Funding Source

Recreation Division maintenance budget.

Department of Public Works maintenance budget.

School Department maintenance budget.

- LIBERTY PARK

Action

Replace broken benches with weather resistant type seating.

Funding source

Department of Public Works maintenance budget.

- MOULTON FIELD

Action

Upgrade ballfield

Resurface tennis and basketball courts.

Replace existing backboards and rims.

Equip both courts with appropriate type nets.

Funding source

Recreation Division maintenance budget.

Land and Water Conservation Fund. 
O'DONNELL FIELD

Action

Construct lighted, regulation size soccer field.

Acquire easement to link O'Donnell Field to Wood Park. Construct a buffer of plantings or fencing to isolate proposed link between O'Donnell Field and wood Park from active recreation.

Funding source

Recreation Division maintenance budget.

Land and Water conservation Fund.

- RIVERSIDE PARK

Action

Build an indoor sports complex on an undeveloped portion of the site.

Construct a swimming pool suitable for competition.

construct dance and weight rooms.

construct an indoor track.

Construct tennis or racquetball courts.

Construct a multi-purpose gymnasium.

Funding Source

Bond issue.

Urban Self Help.

- SAINT MICHAEL'S BaLLfield

Action

Acquire site from Archdiocese of Boston.

Funding source

Donation.

Land and Water Conservation Fund.

- sauta property

Action

Develop this newly acquired parcel as an active recreation site. Due to lack of recreation areas in the eastern portion of Hudson, this site should be developed to address the recreation needs of every age group. Activities should range from playground equipment for the very young, to playing fields for children aged 6 to 14 years, an athletic field for young people and adults, a jogging or walking path with exercise stations and a portion retained as undeveloped open space.

Funding source

Land and Water conservation Fund.

self help.

Aquifer Land Acquisition Program. 
Site Recommendations-Continued

TRIPP'S POND/HOG BROOK

Action

Promote use of entire site as a passive recreation area.

Regrade former beach area.

Selectively remove wild shrubs and undergrowth to allow walking paths or nature trails.

Use landscaping to stabilize banks of pond now covered by the beach.

Remove swingset frame.

Funding Source

Recreation Division maintenance budget.

Department of Public Works maintenance budget.

- WOOD PARK

Action

Acquire an easement to connect Wood Park to O'Donnell Field. Construct roof over bandstand.

Clear excessive undergrowth from along the banks of the Assabet River to enhance viewlines and security.

Repair existing lighting.

Funding source

Self Help.

City and Town Commons Program.

Public Access Program.

Acquisition of Land Fronting on Rivers and Streams.

\section{OPEN SPACE AND RECREATION ACTION PLAN}

The purpose of the Action Plan is to rank by priority, all site specific improvements, facility upgrades and land acquisitions recommended in the open Space and Recreation Plan. The Action Plan establishes a five year timeline during which recommendations would be implemented. Like the recommendations section, the Action Plan should be flexible enough to allow for modification or revision in the Plan in response to demographic changes, economic conditions or changing community goals and priorities.

$1987-1988$

- Create, adopt and implement a long range comprehensive maintenance program for all Town-owned open space and recreation areas.

- Construct an active recreation playfield in the southeast portion of the Town using the former sauta Property. The proposed park should provide recreational opportunity for all age groups and include, playground equipment, playfields, an athletic field, jogging or walking paths and exercise stations and retain portion as undeveloped open space. 


\section{ACTION PLAN-CONTINUED}

- Upgrade and expand athletic fields at the John F. Kennedy School. Renovate baseball fields.

Light for night use.

Expand site open portion of the site to create a regulation soccer or field hockey field.

- Clear overgrown trails at Danforth Conservation Area. Institute nature walks and envi ronmental education programs using Townowned open space as an outdoor classrom.

- Replace asphalt surface of Hubert School/Kelly Playground play area with grass or sand.

- Promote Tripp's Pond/Hog Brook as a passive recreation area. Selectively remove a portion of wild shrubs and undergrowth growing on beach to allow walking paths or nature trails.

Link Apsley and Wood Parks to O'Donnell Field and Riverside Park. Acquire a parœl of land connecting the sites through donation, or purchase easement to connect sites, if necessary. Repair bridge connecting both parks. construct roof over bandstand base in wood Park.

Construct lighted, regulation size soccer field in O'Donnell Field. Isolate proposed link between Apsely and Wood Parks by fencing or plantings from portion of site devoted to active recreation.

Resurface tennis courts at Forest Avenue School. Upgrade ballfield.

Light for night use

- Replace broken benches in Liberty Park with weather resistant type seating.

- Acquire Saint Michael's Ballfield from the Archdiocese of Boston to remain in use as an active recreation site.

- Renovate Moulton Field

Upgrade ballfield

Resurface tennis and basketball courts

- Recycle unused Cox street ice skating area into an active recreation requiring little space, e.g. Basketball courts. 


\section{ACTION PLAN-CONTINUED}

- Realign the driveway at the cox Street School to allow greater use of front lawn.

- Enhance recreation opportunity at Cherry Street Playground. Light facility for night use Add a basketball and tennis court Utilize proximity to River to develop waterfront walkways construct exercise stations along walkways

- Build an indoor sports complex on an undeveloped portion of Riverside Park.

Facilities that may be found in such a complex include;

A swimming pool suitable for competition.

Dance and weight rooms.

An indoor track. Tennis or racquetball courts. An all purpose gymnasium.

- Renovate the Chapin Field ballfields. Improve dugouts and spectator seating 
APPENDIX

$-50-$ 
PUBLIC SCHOOL ENROLLMENT BY GRADE

$$
1980-1986
$$

Year

$\begin{array}{lllllll}1980 & 1981 & 1982 & 1983 & 1984 & 1985 & 1986\end{array}$

Grade

$\begin{array}{llllllll}\text { Kindergarten } & 220 & 210 & 220 & 225 & 239 & 203 & 225\end{array}$

$\begin{array}{llllllll}\text { TKindergarten } & 15 & 15 & 13 & 12 & 13 & 15 & 15\end{array}$

one

$\begin{array}{lllllll}183 & 189 & 189 & 209 & 207 & 215 & 164\end{array}$

$\begin{array}{lllllll}197 & 165 & 180 & 190 & 201 & 178 & 198\end{array}$

$\begin{array}{lllllll}199 & 196 & 165 & 182 & 179 & 198 & 169\end{array}$

$\begin{array}{lllllll}214 & 201 & 204 & 178 & 179 & 177 & 194\end{array}$

$\begin{array}{lllllll}260 & 220 & 185 & 209 & 198 & 187 & 162\end{array}$

$\begin{array}{lllllll}235 & 263 & 219 & 187 & 204 & 177 & 178\end{array}$

$\begin{array}{lllllll}249 & 220 & 247 & 221 & 184 & 195 & 179\end{array}$

$\begin{array}{lllllll}261 & 241 & 225 & 245 & 215 & 172 & 191\end{array}$

$\begin{array}{lllllll}188 & 198 & 164 & 161 & 148 & 158 & 125\end{array}$

$\begin{array}{lllllll}204 & 169 & 169 & 168 & 154 & .163 & 166\end{array}$

$\begin{array}{lllllll}212 & 188 & 158 & 160 & 143 & 158 & 141\end{array}$

$\begin{array}{lllllll}215 & 196 & 172 & 158 & 168 & 142 & 160\end{array}$

Source: Hudson School Department 
PUBLIC SCHOOL ENROLLMENT BY SCHOOL

$$
1980-1986
$$

Year

$\begin{array}{lllll}1980 & 1981 & 1982 & 1983 & 1984\end{array}$

$19851986 \begin{gathered}\text { Percent Change } \\ 1980-1986\end{gathered}$

School

Hubert

(kindergarten)

$220 \quad 210$

220

225

239

$203 \quad 225$

$+2.38$

Cox street

$(1-6)$

$\begin{array}{llllllll}342 & 335 & 326 & 331 & 306 & 296 & 298 & -12.98\end{array}$

C.A. Farley

$(1-6)$

$\begin{array}{llllllll}431 & 418 & 375 & 384 & 388 & 400 & 339 & -21.38\end{array}$

Forest Avenue

$(\mathrm{TKK}-6)$

J.F. Kennedy $(7-8)$

Hudson High

$(9-12)$

$\begin{array}{lllllll}587 & 546 & 519 & 512 & 538 & 512 & 506\end{array}$

$-13.88$

$\begin{array}{lllllll}510 & 461 & 472 & 466 & 400 & 367 & 370\end{array}$

$-27.48$

$819 \quad 751 \quad 663$

647

$613 \quad 621 \quad 592$

$-27.78$

Source: Hudson School Department 
POPULATION BY AGE

1980

1980

Age

Under 5

1,149

5

213

225

808

7-9

1,243

14

329

15

318

16

342

17

462

18

314

19

302

20-24

1,414

$25-34$

2,707

$35-44$

1,997

45-54

1,874

$55-59$

733

$60-64$

563

$65-74$

773

$75+$

Total

$\frac{665}{16,431}$ 
TOWN OF HUDSON RECREATION PROGRAMS

Program Name

Cheer leading

Exceptional Children

Exception Sunshine Camp

Playground Program

Swim Instruction

Swim Team

Swim League

Tot Lot

Youth Basketball

Youth Golf Instruction

Youth Gymnastics

Youth Tennis Instruction

Adult Aerobics

Adult Cross Country Ski

Adult Golf Instruction

Adult Tennis Instruction

Volleyball

The Division of Recreation also conducts concerts, cookouts, tournaments and outings.
Number of Participants

$$
\begin{aligned}
& 28 \\
& 16 \\
& 27 \\
& 143 \\
& 494 \\
& 57
\end{aligned}
$$

special recreation programs, e.g. 


\section{OPEN SPACE PROGRAMS}

Information complied by the Executive Office of Environmental Affairs concerning select funding sources for open space and recreation planning in Massachusetts communities follows. All quotations cited below are from open Space Programs an informational booklet, released in January 1987, by the Executive Office of Environmental Affairs.

Acquisition of Land Fronting on Rivers and Streams M.G.L. Chapter 723, section 9A

"The rivers acquisition program identifies and protects parœls of land on Massachusetts' rivers, in particular those that are now of increased aesthetic, recreational and sporting value. The rivers named in the bill are: Charles, Millers, Nashua, Squannacook, Assabet, Housastonic, Shawsheen, Merrimack, and spicket. Any Massachusetts river can be included in this program."

Aquifer Land Acquisition Program

M.G.L. Chapter 723, M.G.L. Chapter 286

"This program provides grants to reimburse municipalities for the acquisition of land to protect groundwater resources. The program has two components: the Phase I study, to determine the zones of contribution around an aquifer, and the acquisition program. the program reimburses for the entire cost of an acquisition, with a maximum grant of $\$ 500,000$ available per project."

Bay Circuit Program

M.G.L. 233 Acts of 1984

"This program provides for acquisition of land in 50 cities and towns lying more or less between Routes 128 and 495, as specified in M.G.L. 631 of Acts of 1956. It also provides for planning grants to those cities and towns."

"The goal of the planning grants and acquisitions is to create a system of parks and open spaces that are connected by roads, trails and waterways. DEM is working with each community to determine the route of the Bay Circuit so that it can meet local as well as regional envi ronmental and recreational objectives. Special criteria have been developed to guide land acquisition decisions."

\section{City and Town Commons Program}

M.G.L. Chapter 723, section $9 \mathrm{~F}$

"This program provides for grants to cities and towns for the development and restoration of city and town commons or centers. The program also provides money for acquisition of land for this purpose."

"This program paves the way for restoration of the cultural and historic centers of communities in Massachusetts and for the subsequent private sector improvement in these areas. All Massachusetts communities are eligible. 
OPEN SPACE PROGRAMS-CONTINUED

All quotations cited below are from open Space Programs an informational booklet, released in January 1987, by the Executive Office of Envi ronmental Affairs.

Land and Water Conservation Fund

"This program is administered nationally by the National Park Service, and in Massachusetts by the Division of Conservation Services, provides reimbursement grants of up to 508 for the acquisition and development of outdoor recreation facilities."

Public Access Program

M.G.L. Chapter 723 section 9K, M.G.L. Chapter 21 section 17A

"This program provides for the acquisition of lake, pond, saltwater and riverfront property for public access to these water bodies primarily for boaters and canoeists. The program also acquires land for trails."

\section{Self Help Program}

M.G.L. Chapter 132A section 11

"This program provides grants of up to 808 of project cost to municipalities for the acquisition of public open space for passive recreation and conservation purposes. It allows comminities to keep open important areas for local outdoor activities, educational purposes and environmental protection, including reservoir protection, trails, watershed protection, fresh and salt water access and beaches, wetlands, archeological sites and farmland." 